\title{
Újabb adalékok az ún. „,corona latina” datálásának problematikájához
}

\author{
ARADI CSILLA \\ KJH, Járási Építésügyi és Örökségvédelmi Hivatal, 7400 Kaposvár, Csokonai u. 3., \\ e-mail: csiaradi@freemail.hu
}

\begin{abstract}
ARADI, Cs.: New information to the problematic dating of the so called "corona latina".

Abstract: The paper deals with the various analogies to the 12. C. dating possibility of the upper part of the Holy Crown of Hungary, the "corona latina" through technical and imagery aspects. It also gives a brief insight into the versatile relationship of the Byzantine Empire and the Hungarian Kingdom during the turn of the $12-13$. C.
\end{abstract}

Keywords: Holy crown of Hungary, apostles, Pantocrator, enamel technique, inscriptions, filigree, keys

\section{A korábbi kutatás összegzése}

Míg a hazai művészettörténeti és régészeti kutatás a corona graeca készítési idejét általánosan a 11. század második felére helyezi és csak a korona hátsó részén elhelyezkedő Dukasz lemez (és talán a Géza és Constantinus) utólagos rögzítése okoz problémát, a latin koronarész datálása már meglehetősen problematikus. Míg egyes kutatók készítését a 10-11. század fordulójára helyezik, mások 12-13. századi létrejöttét is valószínűnek tartják. Már a 90-es években lefolytatott ötvös vizsgálatok is felvetették egy későbbi készítés lehetőségét - és azt az 1083-ban szentté avatott Szent István számára készített fejereklyetartóként értelmezve állították, hogy a latin Pantokrátor lemez készült a görög alapján és nem fordítva, ahogy azt a kutatók többsége feltételezte. ${ }^{1} \mathrm{~A}$ kései keletkezést támasztotta alá Albert Boeckler, Deér József, Vajai Szabolcs és David Buckton munkássága. Mind a lemezek eredeti funkciójával (könyvborító, sztaurothéka, fejereklyetartó, liturgikus csillag), mind pedig készítési helyével kapcsolatban számos elmélet született, Itáliai (Szicília, Velence), Antióchiai, Rajna vidéki, Regensburgi, Aquitániai és magyar lehetőség is felmerült. Abban a kutatók nagy többsége azonban egyetértett, hogy a zománclemezek a filigránból készített pántra valamikor a 12. század végén, III. Béla uralkodása idején kerülhettek. ${ }^{2}$ Jelen dol-

1 Péri-Papp 1994. 9

2 Ipolyi Arnold: A magyar szent korona és a koronázási jelvények története és müleírása. Budapest 1886., Czobor Béla: A magyar szent korona és koronázási palást. In: Forster Gyula szerk.: III. Béla Magyar király emlékezete. 1900. 98-114., Varju Elemér: A Magyar Szent Korona. Archeológiai Értesítő, XXXIX. 1920-22., Moravcsik Gyula: A Magyar szent korona a filológia és történeti kutatások megvilágításában. In: Serédi Jusztinián szerk.: Emlékkönyv Szent István halálának 900. évfordulóján III. Budapest 1938. 426-472., Deér Josef: Die Heilige Krone Ungarns. Graz-Wien-Köln 1966., Bárányné-Oberschall Magda: Die Sankt Stephans Krone und die Insignien des Königreiches Ungarn. Wien-München 1961. 1974, Vajay Szabolcs: Az Árpád kor uralmi szimbolikája. Memoria Saeculorum Hungariae.Budapest 1974, FrantzBock: Die ungarische gozatnak nem célja ennek a problémakörnek az eldöntése, azonban 1-2 adalékkal szeretnék hozzájárulni a már korábban felvetett későbbi datálás lehetőségéhez, és annak megfontolásához, hogy az ún. corona latina lemezeinek készítési ideje és a korona összeállítása közötti időszak jóval szűkebb időintervallum, mint ami a köztudatban meggyökerezett.

Már Deér József felvetette, hogy csak a rendszeres stiláris és technikai összehasonlítások hozhatnak elmozdulást a korona tanulmányozásában. ${ }^{3}$ Úgy tünik, hogy a technikai szempontú megfigyelések a koronakutatásban másodlagos szerepet kaptak, sokkal inkább az ábrázolt személyek foglalkoztatták a kutatókat. Dolgozatomban elsősorban az apostollemezekkel és a Pantokrátor lemezzel foglalkozom, amelyek behatóbb vizsgálata során több szempontú megfigyelést kell tennünk. Azt már Tóth Endre is megállapította, hogy a keretükből kivehető zománclemezek - vagy a Pantokrátor lemezzel együtt, vagy attól függetlenül - egy korábbi ötvöstárgyhoz készülhettek, amelyet később szereltek fel a filigrános kerettel és fehér igazgyöngyökkel, valamint bordó almandin kövekkel díszített keresztpántra (amelynek vége sima felülettel illeszkedik az abroncshoz). ${ }^{4} \mathrm{~A}$ kérdés tehát abban rejlik, hogy készülhettek-e ezen zománclemezek a 10-11 században, vagy esetleg egy későbbi időszakra tehetjük létrejöttüket.

Ma már a kutatás abban is egyetért, hogy az ún. corona latina lemezei nagyobb részt bizánci művészeti hatásra készültek, és hogy a korona egybeszerkesztése is a bizánci uralkodók befolyását valószínűsíti. Mint köztudott, a Komnenos dinasztia idején, a 12. sz. elején jelenik meg a félgömb alakban zárt koronák, az ún. kamelaukion típusa, amelynek első viselője I. Alexios (1081-1118) volt. ${ }^{5}$ (3. ábra.) Ennek jó állapotban megőrzött aranyborításos, drágakövekkel ékesített példá-

Königskrone. München 1978., Kovács Éva-Lovag Zsuzsa: A magyar koronázási jelvények. Budapest 1980., ed. Lovag Zsuzsa: Insignia regni Hungariae. 1. Studien zur Machtsymbolik des mittelalterlichen Ungarn. Budapest 1983, Tóth Endre: Zur datierung der Apostolplatten der Heiligen Krone, in Communicationes Archaeologiae Hungariae, 1996, 181-209. Tóth Endre: A magyar Szent Korona. Királyok és koronázások, Budapest 1999., Tóth Endre: A Magyar koronáról és a koronázási jelvényegyüttesröl. In: Veszprémy László szerk.: Szent István és az államalapítás Budapest 2002. 209-226., David Buckton: The Holy Crown in the history of enamelling. In: Marosi Ernő szerk.: La Sainte Couronne de Hongrie. Acta Historiae Artium 43. 2002 14-21.

3 Deér 1966. (2005)

4 Tóth Magyar Szemle XX.

5 A bizánci koronatípus kialakulásáról Anna Komnéna apjáról írott müvében ír. 
nya a palermói dóm kincstárában látható, feltehetően Palermóban készült görög munka (ahol már a 12. században is működött királyi mühely, elég csak a királyi palástra gondolni) és eredetileg Frigyes feleségének, aragóniai Konstanciának sírjából került elő. ${ }^{6}$ (2. ábra.) Vajay Szabolcs vetette fel azonban azt a tényt, hogy a magyar korona csak olyan kamelaukion-szerü koronának tekinthető, mivel valójában egy stemmatogyrion koronát (corona graeca) próbáltak - feltehetően sietve - átalakítani.
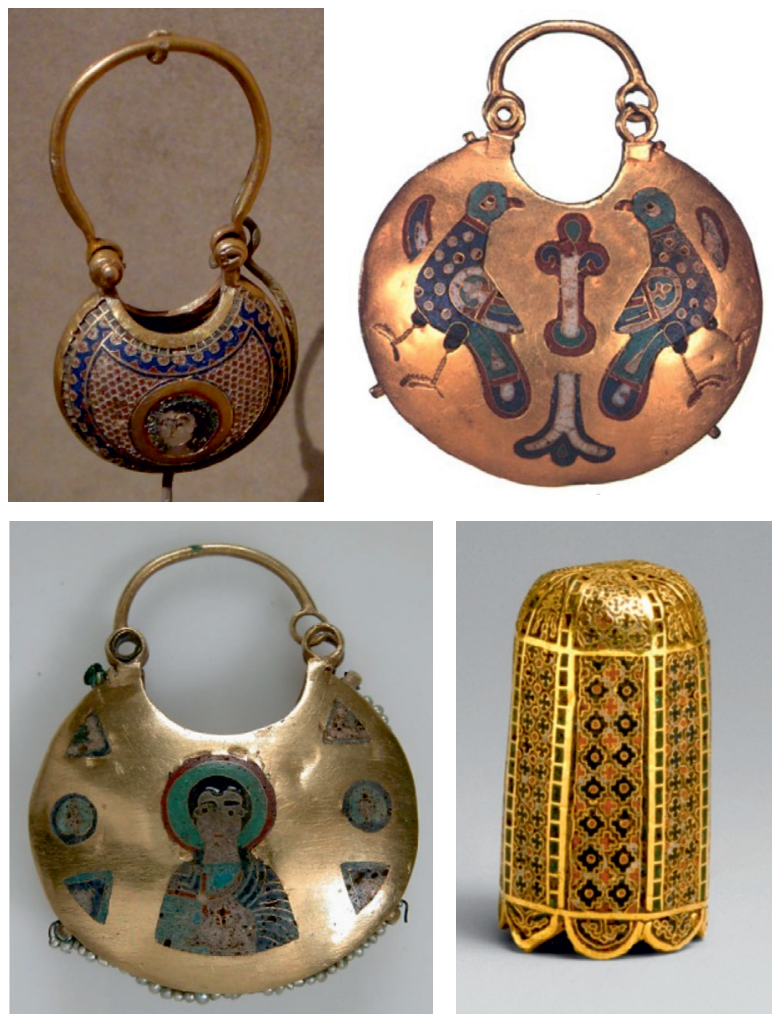

1.ábra. Bizánci és kijevi homlokfüggők és mutató hegye a 11-12. század fordulójáról)

\section{Technikai szempontú megfigyelések:}

Az apostolokat ábrázoló lemezek átmenetet képeznek az ún. cloisonné és a későbbi champlevé zománctechnikák között, vagyis a 10. századtól Bizáncban elterjedt technika mellett - mikor az arany alapba kalapált díszítést töltötték ki másodlagosan vékony drótból hajlított rekeszekkel - a 11. század végétől fokozatosan tért hódít az a megoldás, mikor a későbbi zománccal díszítendő részeket az alapba vésik, ami a rekeszek szerepét váltja ki. Így az arany alap egyes részletei a felszínen is láthatóak. Az így kialakított sávok, körök közeit általában az aranylemezre ráapplikált rekeszek díszítették. A korábbi nagyobb arany háttér ezzel párhuzamosan beszűkült, geometrizálódott. Ez a technikai újítás Bizáncban fejlődött ki a 11-12. szá-
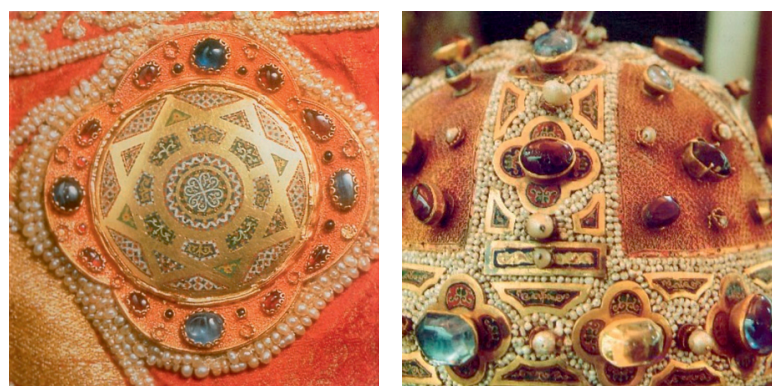

2. ábra. Zománcdíszités II. Roger király palástjáról és részlet Konstancia koronájáról

zad fordulóján, de végül a nyugati művészetben éri el csúcspontját, elég itt a Meuse-vidék fémmüvességére utalnunk. A vegyesen alkalmazott technológia ott sem volt ismeretlen. A 11-12. század fordulójától úgy tűnik, hogy divatba jött a korábbi zománcok újrafelhasználása, újabb zománcokkal való elegyítése, így nem egyszer a kétféle zománctechnika egyazon alkotáson jelenik meg. Ennek talán legismertebb példája a méretek és levágott zománclemezek tanúsága szerint másodlagosan egybeszerkesztett Vercelli evangeliárium fedele. Hasonlóan másodlagosan elhelyezett elemekből készítették a Chiavennai könyvborítót, melyet feltehetően 1176-ban Cristiano de Magonza püspök ajándékozott a Chiavennai templom számára. Bár a bizánci művészetben még alapvetően a rekeszdíszítés dominál, de már megjelennek a keretezésnél, a díszítések elválasztásánál a szélesebb, alapba mélyített formák, először a császári, majd a helyi mühelyek munkáiban. A két részből álló, középen üreges homlokfüggőt két oldalt egy karikával a hajba fonták vagy a fejdíszhez rögzítették. A bizánci arisztokraták viseletét később a kijevi Rusz helyi mühelyeiben is utánozták és Kolty néven nagyon elterjedtté vált. Sajátos módon, többet egybekapcsolva viselték, és a díszítésekben is megjelentek a helyi változatok, madarak, griffek, szentábrázolások. Némely darabon az eredeti gyöngykeretezés is megmaradt. $^{7}$ (1. ábra)
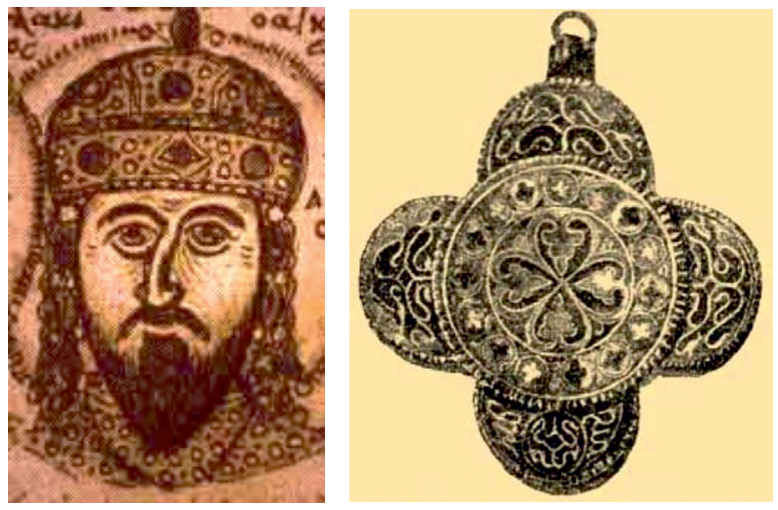

3. ábra. II. Izsák Angelosz kamelaukionnal a fején és enkolpion III. Béla sírjából 

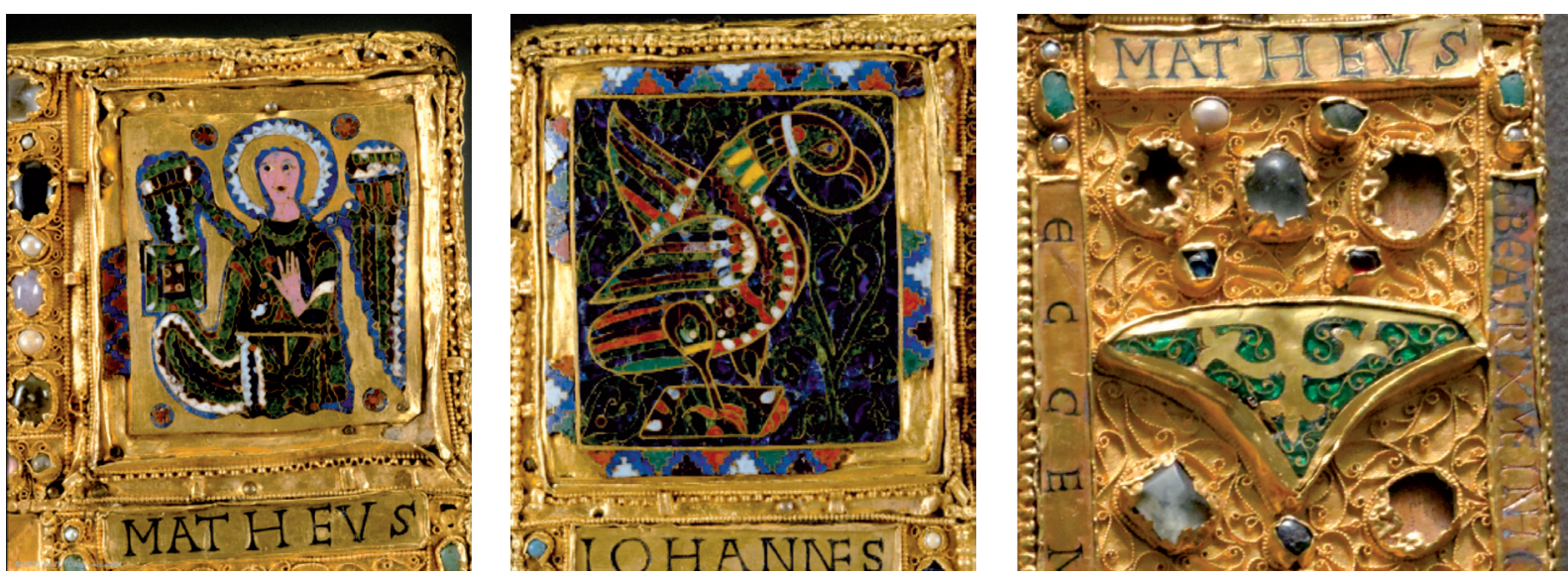

4. ábra. Máté és János evangélista és háromszög veret a Maastrichti könyvborítóról

Bár az apostollemezek teljes felülete díszített, nem egyforma módon tagoltak, van ahol a lemez keretén kívül csak a feliratot elválasztó sáv és az alak körvonala van kiemelve, míg Pál és Jakab esetében a felső, állatpárral történő díszítés hasonló módon, tagoló sávval válik el az oldalsó geometrikus díszítéstől. Szt. Péter esetében ezt az elválasztást egy egyszerü rekesszel oldották meg, amelyen egyben a szárnyas állat (griff?) áll (ez a földet jelző vonal Jakab apostol esetében is megfigyelhető), míg a másik négy esetben ez is hiányzik.

Az apostolalakok rekeszeit vizsgálva szembeötlő, hogy azok nem követik a korábbi, 10-11. századi bizánci zománcok sürü és finom rekeszelési technikáját, ezzel szemben karakteresebb hajlításokat alkalmaznak, a $V$ alakú és közel párhuzamos szalagok mellett, ívelt és félhold alakú rekeszek is megfigyelhetők. Talán a legnagyobb különlegesség a cikkcakk alakban meghajlított rekeszek, drótok mutatják, melyek csak elenyésző számú párhuzammal rendelkeznek. Az eredetileg a Maastrichti katedrális kincstárában, jelenleg a Louvre-ban őrzött, Trieri/Regensburgi munkának tartott és a 11. sz. első felére datált keresztrefeszítés jelenetével díszített könyvborító evangélistákat ábrázoló lemezein is előfordul cikkcakk alakban hajlított drót. A zománclemezek érdekessége - hogy a koronához hasonlóan - mindkét technika jelen van egyazon alkotáson. A növényi ornamentikával ellátott, ívelt háromszögletủ díszítések és a filigránkeret, valamint a betűk kialakítása az összeállítást illetően legalábbis egy későbbi datálást sejtet. ${ }^{8}$ (4. ábra)

Egy Thesszalonikiből származó, 1200 körüli ereklyetartó kereszt vízszintes szárvégződésein hasonló, cikkcakk alakú drót található, Jézus bordáinak kialakí-

8 Eddig a kutatásnak a 11. századból nem sikerült megnyugtató módon tisztázni az adományozó - a felirat alapján Beatrix - kilétét. Adódik azonban annak a lehetősége, hogy az adományozó személyét Barbarossa Frigyes feleségéhez, Beatrixhez (1143-1184) kössük. A burgundi gróf lánya Beatrix 1156-ban lett az addigra már német-római császárrá koronázott Frigyes felesége. A könyvborító korábbi elemek felhasználásával a 12. század második felében kerülhetett feltehetően a S. Szerváciusz templom birtokába. tása pedig az apostolok ívelt, kevésbé sűrű rekeszkiképzését idézi. (5. ábra) A kereszt ritkásabb rekeszeiben és színvilágában is párhuzamot jelent (ld. pirossal keretezett fehér keresztes zöld dicsfény). A kereszt - amelyet gyakran kötnek a Koppenhágában őrzött Dagmar kereszthez, illetve a Londonban örzött Szt. György és Demeter ereklyetartóhoz, feltételez egy Thessalinikiben működő műhelyet, amelynek 12-13. századi felvirágzása a Szentföld mohamedánná válásával egyre fontosabbá váló Szt. Demeter szentély központi szerepével magyarázható. ${ }^{9}$

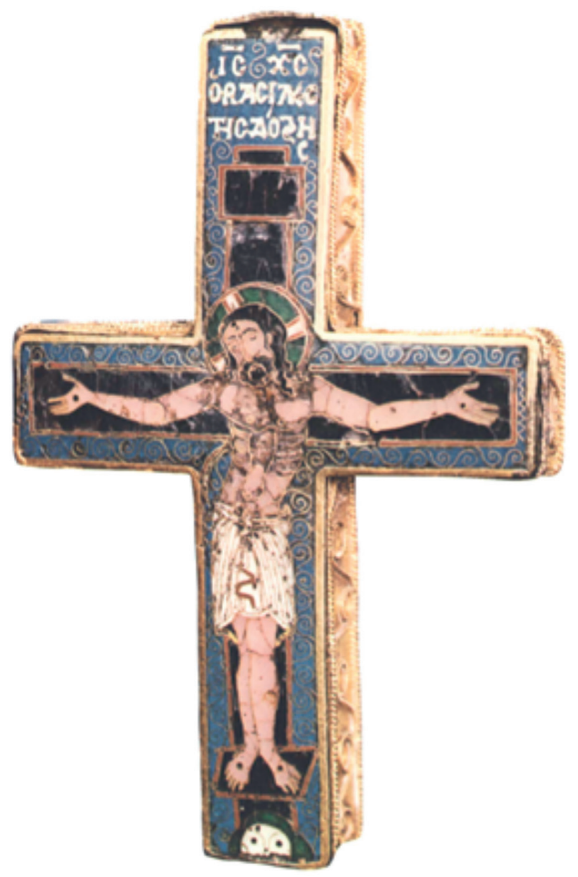

5. ábra. Ereklyetartó kereszt Thesszalonikiböl

$9 \quad$ Evans-Wixom 1997. 174 


\section{Ábrázolással, díszítéssel kapcsolatos megállapítá- sok:}

Attribútum gyanánt az apostolok vagy egy könyvet, vagy irattekercset tartanak, ami alól Szt. Jakab jobbjában tartott liliomos jogar és Szt. Péter bal kezére akasztott és jobbjában tartott kulcs jelent kivételt. ${ }^{10}$ Míg Jakab esetében a jogarszerü tárgy esetleg zarándokbotként is értelmezhető, Péter esetében az oldás és kötés kulcsainak jelenléte - legalábbis a nyugati művészetben a Karoling korra nyúlik vissza. Bár Tóth Endre több tanulmányban foglalkozott a kulcsok csuklóra akasztható típusával, azonban a kulcsfejek szögletes, rombusz alakját nem figyelte meg. Pedig ez a formájú kulcs elég későn, csak a 12. században jelenik meg, talán egyik első megnyilvánulása egy Leoni elefántcsont ereklyetartó ábrázolás a század első feléből, vagy egy Meuse/Maas-vidéki alkotás valamivel későbbről. (6. ábra) Magyarországon a 12. század második feléből származó, Szt. Pétert ábrázoló somogyvári (1170-90), valamint a 13. század elejére keltezhető gyulafehérvári kőfaragáson találunk hasonló kulcsokat. (7. ábra)

$\mathrm{Az}$ apostolalakokat térkitöltő hatású díszes keret övezi, melyek alsó részén geometrikus lépcsőminta, körbe foglalt négykaréjos és hármas levelekben végződő indás díszítés foglal helyet, míg felül 2 esetben szárnyas állatpár és 3 esetben madárpár található. Míg az állatokat övező szabad területet a négykaréjos díszítés tölti ki, a madarak esetében ez csak András apostolnál figyelhető meg, a másik 2 esetben a madarak indák közt láthatóak. Fülöp és Tamás apostolok feje mellett, az oldalsó díszítéstől elkülönülő, indás díszítés található. ${ }^{11}$ Míg többségében a két oldalon egyazon mintát találunk, János apostol jobbját karéjos, balját indás díszítés övezi. Az alak feletti névalkotásban is eltér a többi apostoltól, érthetetlen, hogy miért kellett nevének rövidítéséhez folyamodni, hiszen a ScSIOHANNES és a ScSPHILIPVS egyforma betüszámú, igaz, hogy Szt. János nevében szélesebb kiterjedésű betűket találunk. ${ }^{12}$ Feltehetően ez a rövidítésforma olyan elterjedt volt, hogy meg sem fordult a készítő fejében a teljes név kiírása, ezért kellett folyamodnia a név előtti és utáni üres helyek négykaréjos díszítéssel való kitöltésére. Itt kell megemlíteni, hogy a görög Pantokrátor lemez mögötti sérült Bertalan apostol lemezen 1983-ban nevét ARTHOLO-ként olvasták, és nem emlékeznek meg az előtte lévő ScS rövidítésről. Azonban a betűk számát vizsgálva felvetődik, hogy a rövidítés pont annak tudható be, hogy eredetileg ScSBARTHOLO névalak szerepelt, csak a név eleje megsérült. Ily módon ábrázolja Rauscher

10 Itt kell megjegyezni, hogy Fülöp apostol kezében tartott tárgy csak kis jóindulattal nevezhető könyvnek, püspöksüveggel való ábrázolására azonban nincs párhuzam.

11 Hasonló indadíszítéssel a Pantokrátor körüli ciprusok lombjában is találkozunk, de ilyen típusú díszítés a Pala d’Oro négykaréjos Szt. Mihály arkangyalt ábrázoló zománclemezén is előfordul. Deér 2005. LXXXVI. tábla

12 Fülöp helyesen Philippus, így analógiaként használhatták volna János nevét is megrövidítve Johanes alakban.

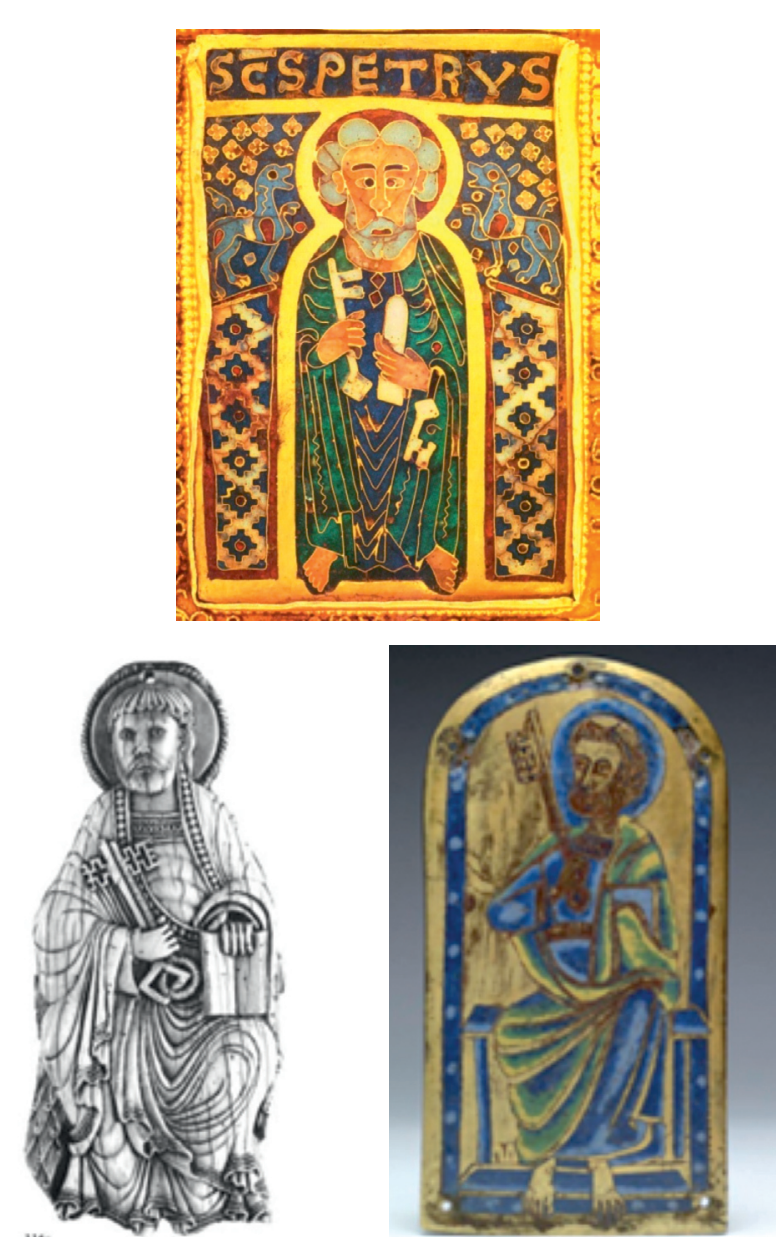

6. ábra. Szt. Péter alakja a koronáról, egy leoni ereklyetartó ládikáról és egy Maas-vidéki zománcveretről

Lajos a Szt. Bertalan lemezt Ipolyi 1886-ban megjelent könyvében. ${ }^{13}$ (8. ábra) Nincs jogunk feltételezni, hogy ennél az apostolnál nem szerepeltették a szent előtagot. A betűk típusvizsgálatával Tóth Endre foglalkozott kimerítően, ${ }^{14}$ így itt csak néhány további észrevételre hívnám fel a figyelmet. A betűkről általánosságban elmondható, hogy nem túlzottan konzekvens az alkalmazásuk, elég csak a többféle $A$, T és $V$ betüre gondolnunk. Ugyancsak különlegesség János nevében szereplő kurzív h betű alkalmazása. Eddig talán kevésbé volt tárgyalva a ScS rövidítés, ahol a középső C fölött szerepel a ligatúra.

A 12. század folyamán több nyugati ötvöstárgyon is megjelentek a körbefutó, vagy keretbe foglalt zománc feliratok, erre jó példa a Pala d'Oro diakónusokat és Szt. Márk életét ábrázoló lemezei, vagy az ún. Sioni/Sitteni könyvtábla borítójának körbefutó, Jézust övező kerete. Már David Buckton is rájött, hogy

13 Ipolyi 1886. 140.

14 Tóth 1996. 190-192. Ebben a cikkében Tóth idézi D. Buckton észrevételeit, aki az apostollemezek és a Sioni/Sitteni könyvtábla (1140-1150) zománcfeliratának párhuzamaira hívta fel a figyelmet. Míg a nyugati múvészetben ritka, a bizánci zománcmúvességben elterjedt volt a zománcos betűk alkalmazása. 


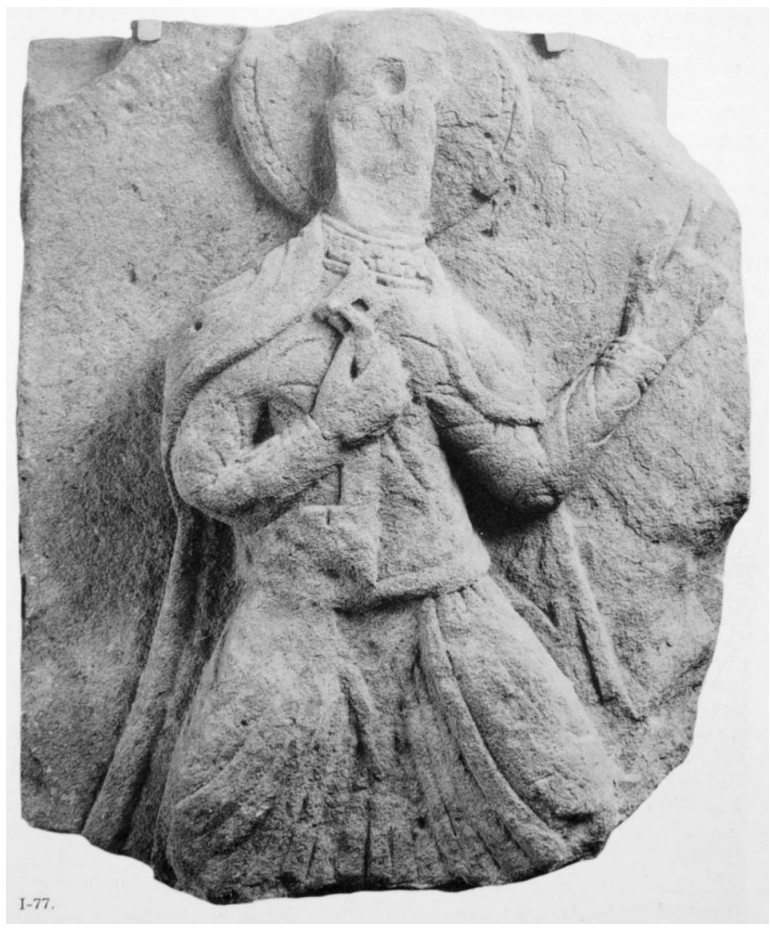

7. ábra. A somogyvári Szt. Péter relief

a könyvtábla felirata több ponton is párhuzamosságot mutat az apostollemezek feliratával, pl. az A betü formai kialakításában, míg a ScS rövídítés mindkét emlékanyagban előfordul. ${ }^{15}$ (10. ábra) A Pala d'Oro Szt. Lőrincet ábrázoló lemezén, Szt. János apostolt ábrázoló képhez hasonlóan a név előtt és után körbe foglalt négykaréjos díszítést találunk. Ugyancsak a koronán található névhez hasonló módon rövidítették János nevét a Pantokrátort övező evangélikusok ábrázolásánál. (9. ábra)
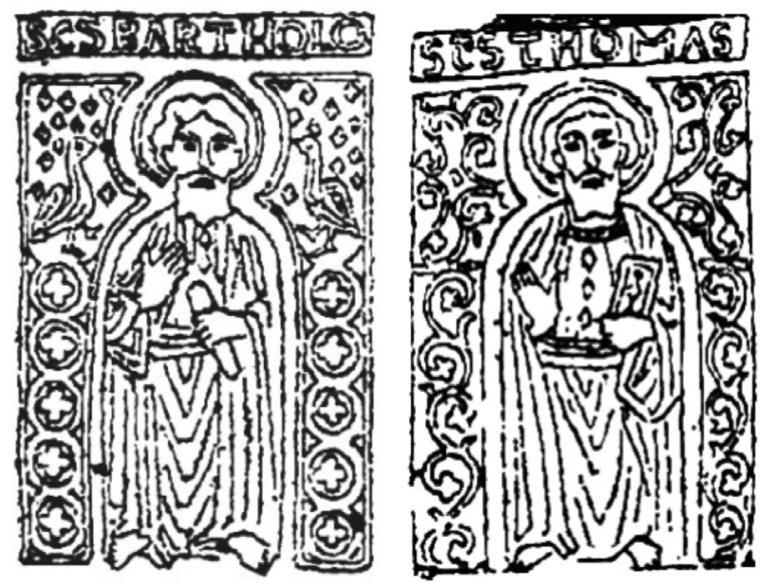

8. ábra. Szent Bertalan és Szent Tamás, Rauscher Lajos rajza
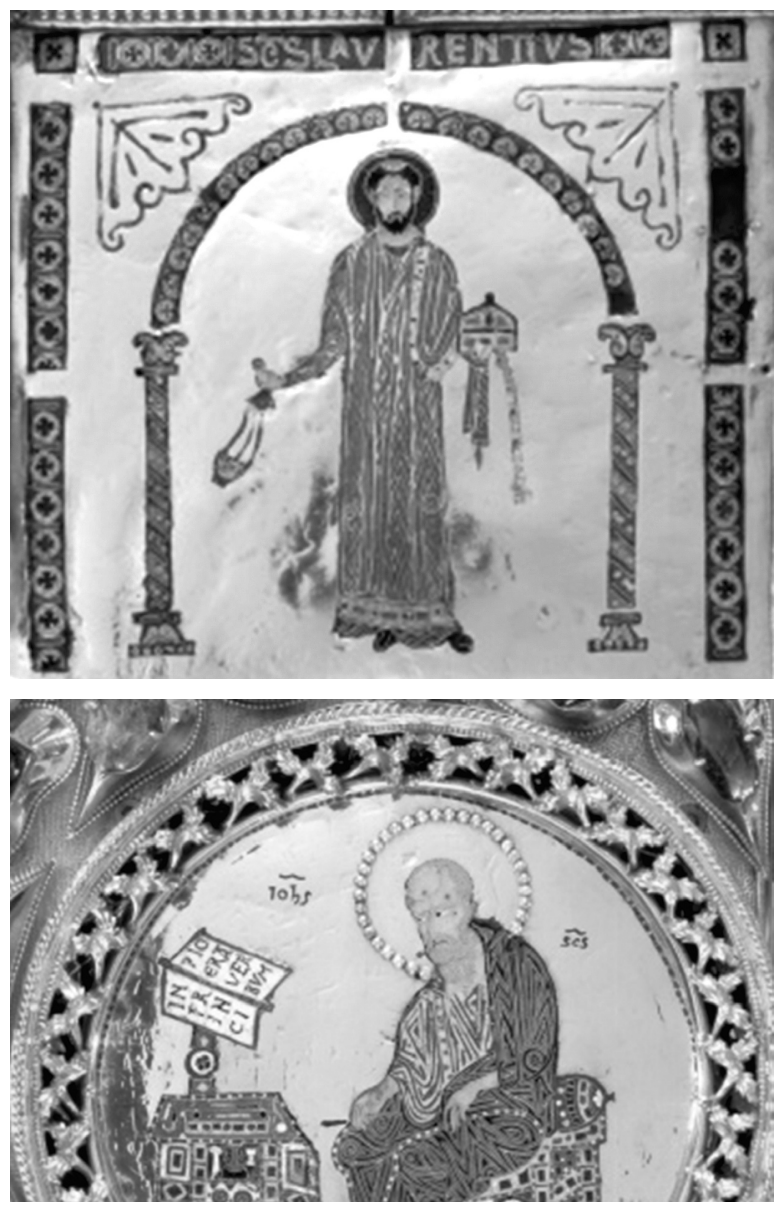

9. ábra. Pala d’Oro, Szt. Lőrinc és Szt. János felirat. 12. századi velencei munka

Ezek a rövidítések a Meuse/Maas-vidéki és német ötvöstárgyakon is előfordulnak. Feltűnő, hogy a betűket 1-1 tárgyon is többféle írásmóddal jelenítik meg, mintegy átmenetet képezve a maiuscula és a kurzív írásmódok között. Ugyan nem ötvöstárgy, de hasonló írásmódot találunk a pécsi székesegyház Szt. Bertalan apostolt ábrázoló relief feliratánál is. (11. ábra) Érdemes az ábrázolásmódban (szembeforduló alak, jobb

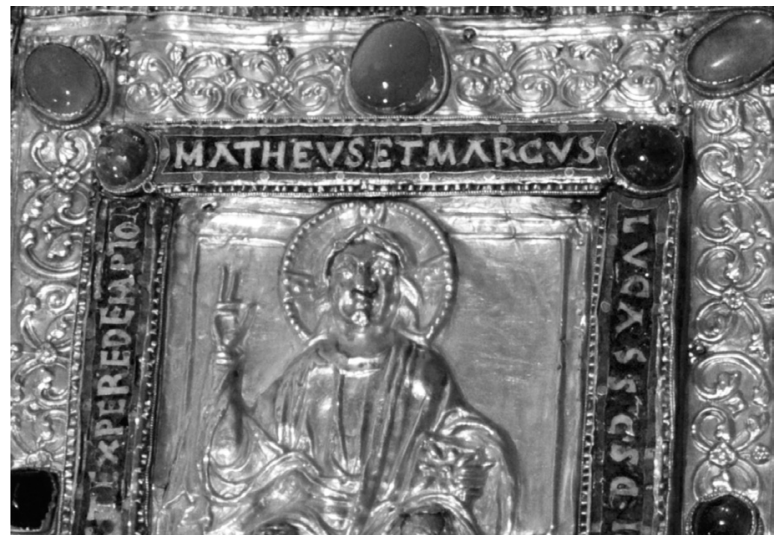

10. ábra. Sioni/Sitteni könyvtábla (1140-1150, Trier?)

15 Buckton 1983. 136 


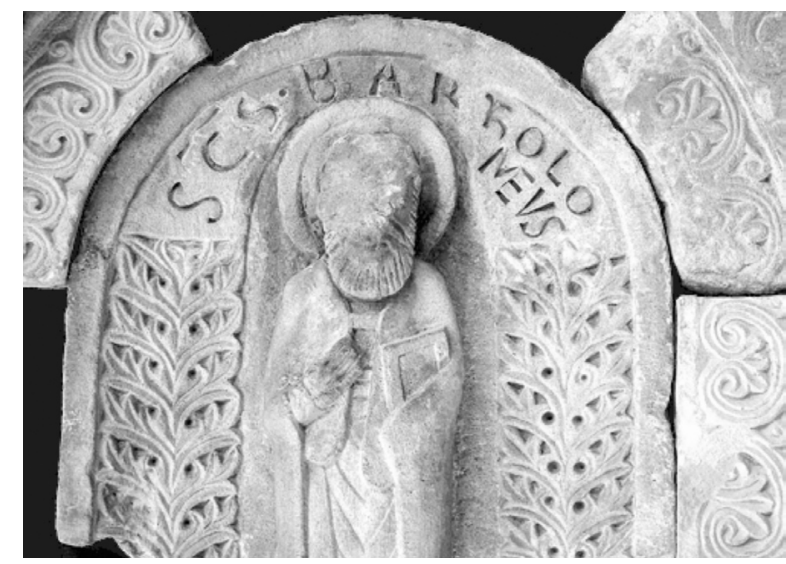

11. ábra. Apostolábrázolás a pécsi székesegyházból, 12. sz. második fele

keze mellén, baljában könyvvel, két oldalán növényi díszítéssel) és a ruha $V$ alakú redőzésében rejlő hasonlóságokat is figyelembe venni. ${ }^{16}$

A nyugati művészetben a redőzés természetközelibb, mozgalmasabb, míg a bizánci múvészetben merevebb, ornamentálisabb volt. Úgy tünik, hogy az apostollemezek redőzése mintegy átmenetet képez a kettő között.

A bizánci művészetben ritka az apostolok álló helyzetben való megjelenítése, sokkal jellemezőbb volt a mellképi ábrázolás (Id. II. Henrik perikópakönyve, VI Leó fogadalmi koronája, a Romanos kehely vagy a nyugati művészetet képviselő, az Ottó-korból származó Szt. Péter pásztorbot), és kivételt képez a Limburgi Sztaurotéka, ahol az apostolok egész alakkal szerepelnek. Ugyanakkor a 11-12. században a nyugati művészet terén szinte kivétel nélkül álló, árkád alatt elhelyezkedő apostolábrázolásokkal találkozhatunk (pl. a Welfi kincs részét képező hordozható oltár, vagy az Aacheni oltár), és úgy tűnik, hogy később ez az ábrázolásmód a bizánci müvészetben is visszhangra talált (Id. Pala d'Oro, vagy a kijevi diadém zománcai).

Bár a bizánci zománcművészet eredetileg nem törekedett a térkitöltés ilyen mérvű alkalmazására, a 11-12. század fordulójától egyre erősödő arab kapcsolatoknak köszönhetően megnőtt a díszítéssel borított felületek aránya. A kultúrák egymásra hatása figyelhető meg az ún. Artukida, vagy a mai örzési helye alapján Innsbrucki tálon, amely Rukn al-Dawla Da'ud (1109-1144) uralkodása alatt készült. A medalionba foglalt mitológiai állat és zenélő, verekedő emberalakokkal, valamint a köztes részen növényi ornamentikával, fákkal, táncosokkal, zenészekkel sűrűn díszített, az ábrázolásban szimmetriára törekvő tál közepén Nagy Sándor apoteózisát láthatjuk. (12. ábra) Bár az apostolábrázolásokkal és a Pantokrátor lemezzel sok tekintetben párhuzamosságot mutató tál (állatalakok, geometrikus, négykaréjos keretezés, indák, cipruspár), a tál ábrázolásvilágának

16 A kőfaragványok létrejötte Makár püspökségéhez köthetők, akit még II. Géza helyezett a püspökség élére, és aki III. István alatt bizánci befolyás alá került (föleg a pécsi püspökséghez tartozó Szerémség okán), 1163-ban pedig rövid időre IV. Istvánhoz pártolt.

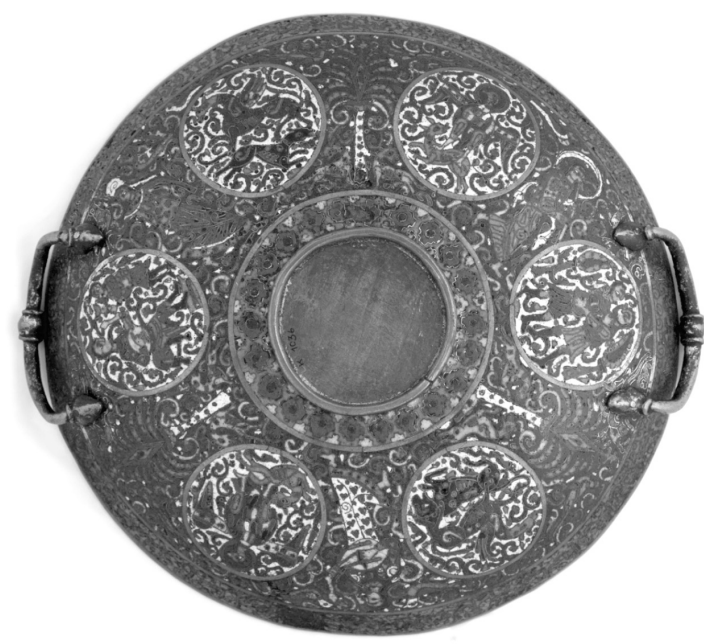

12. ábra. Az ún. Artukida tál hátoldala

mozgalmassága a korona szembenéző alakjainak statikusságától idegen. A zománctechnikával díszített tál ábrázolásmódja mindenesetre utal a Bizánci birodalom és a környező királyságok közti kulturális hatásra. Hasonlóképpen a teljes díszítettségre törekedtek a Figdor gyűjtemény részét képező, aranyozott vörösréz ládika fedelén és oldalán, az indákkal és madarakkal sürün körülölelt 6 egész és 2 csonkított medalionba, György Ágota, Mária, Jézus, Keresztelő Szt. János, Simon, Júdás és Demeter mellképe került. Az alakok mozgalmasságát, mely a hajak ziláltságában is megnyilvánul, a ruharedők finomsága és változatossága is alátámasztja. A szentek nevének hibás, részben latin formái egy Bizáncon kívüli mühely létére utalnak. (13. ábra)

Hasonlóképpen a teljes felület díszítésére törekedtek a már Deér által is az apostollemezek párhuzamaként megjelölt Herakleiai $\mathrm{S}$. Theodore ábrázoláson. Ennek az új stílusnak talán legkifejlettebb formáját a Velencében őrzött, részleteiben plasztikusan kiképzett, a 12-13. század fordulójára keltezhető Szt. Mihály ábrázolás jelenti. Ennek, már a velencei zománcművességre jellemző, kis drágakő vagy üvegberakásokkal díszített külső keretezése, Bizánc keresztesek általi kirablását követő időben készült.

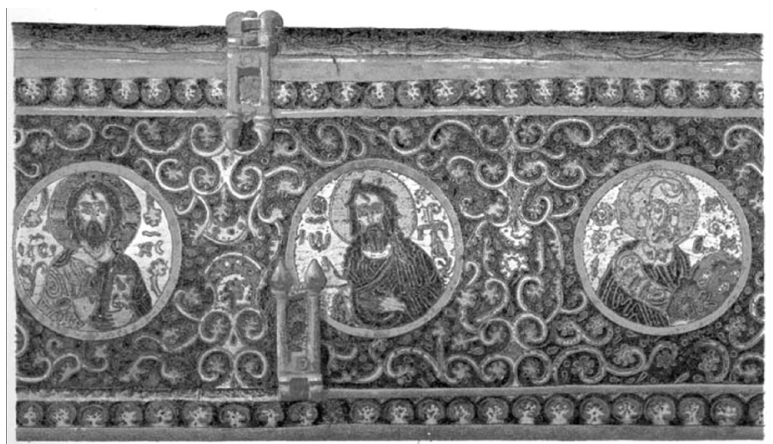

13. ábra. Láda a Figdor gyüjteményből 


\section{Pantokrátor ábrázolás:}

Az apostollemezekre jellemző teljes díszített felülettel ellentétben a Pantokrátor lemez a hagyományosnak mondható, az aranyalapot is láttató cloisonné technikával készült. A koronán elfoglalt helye mindenképpen talányos, érdekessége abban is rejlik, hogy a corona graecan már szerepel egy Krisztusábrázolás - ez a kettős Megváltó ábrázolás egyazon tárgyon különös. Bár első ránézésre az apostollemezektől elkülönül, a kisebb részleteket figyelembe véve, majdnem biztosra vehető, hogy egyazon időpontban készülhetett, és talán ugyanazt a tárgyat díszíthette. A vékony drótból hajlított, kevéssé sürü rekeszek ugyanúgy megjelennek rajta, mint az arckiképzés feltűnő hasonlósága (haj választék, fülek, egyenes szemöldök, orr és száj vonala). Mind színben, mind pedig formában az indás keretdíszítés jelenik meg a két oldalt álló ciprus lombjában, és a ruhákon lévő kisméretű pötty/ rombusz díszek is hasonlóak. Krisztus ruhájának redőzése azonban gazdagabb, mint az apostoloké, koncentrikus félkör, csigavonal, ág alakú és ívelt hajlítások is előfordulnak.

Az ábrázolás módja több szokatlan megoldást mutat. A támla nélküli trónszék ábrázolása először a nyugati mủvészetben jelenik meg, de a 12 . századra már a keleti ábrázolásokon is feltünik. Az ábrázolás különlegessége a kék színű felsőruhából kilógó, piros szegélyű fehér alsóruha láttatása, és a bal kézzel magasan markolt könyv. Hasonló kéztartás több kódex Pantokrátor ábrázolása mellett ${ }^{17}$ egy Grúziából származó és a 13. sz. elejére datált, a Gelati kolostorból származó zománcon is megfigyelhető, ahol a lábtartás is a korona zománcát idézi, bár itt egyértelmű, hogy az alsóruha függőleges aranydíszítésével van dolgunk. I. Ulászló cseh fejedelem 1120-25 között vert dénárján hasonlóképpen válik láthatóvá az uralkodó bal lábszára és hasonló, Imre király trónoló alakja az 1202-es aranybullán, melyre már Deér is felhívta a figyelmet. (14. ábra) Itt a ruha alsó, félköríves redőzése is a Pantokrátor lemezre utal, bár ebben az esetben a felső ruházat a bal térdet nem hagyja fedetlenül. ${ }^{18}$

A Nap és Hold megjelenítése a keresztre feszítés ábrázolása során, valamint megszemélyesített alakban a Maiestas ábrázolásoknál már a kora középkortól ismert, de csak a 12. század második felétől találunk párhuzamot erre az uralkodói pecséteken, pénzeken. Talán az első hold és csillagábrázolás III. Bohemond antióchiai uralkodó dénárján fordul elő, ahol az előlapi sisakos fejábrázolás két oldalán 1-1 holdat és csillagot jelenítettek meg. A hátlapi holdábrázolás sokkal inkább a sziglák körébe sorolható, és hasonlóképpen nem feltételezhetünk hasonló tudatosságot a III. István érme félhold és csillag ábrázolásánál sem. (15. ábra) Krisztus alakját övező két csillag ábrázolás Mánuel

17 Többek között III. Henrik (1043-46) és Oroszlán Henrik (1175-88) evangéliuma és Melisende zsoltároskönyve (1131-43) is hasonlóképpen ábrázolja a Megváltót.

18 Deér 2005. 135.
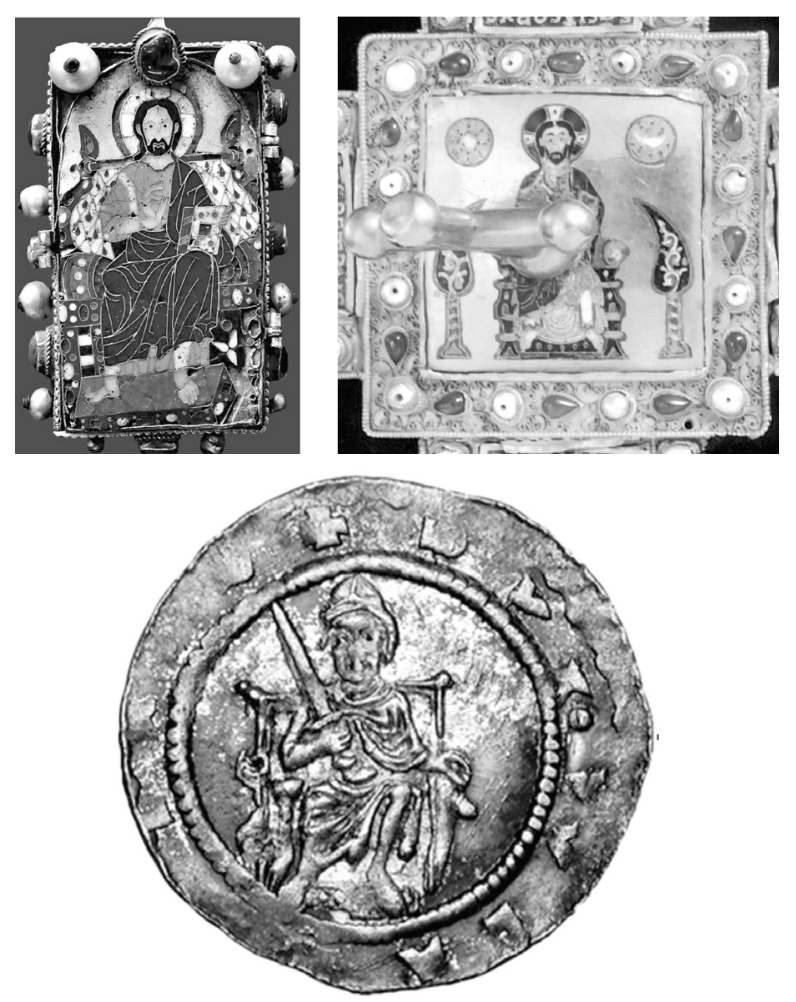

14. ábra. A Gelati és a corona latina Pantokrátora, valamint I. Ulászló pénzérme

császár érmein is előfordul. Az antióchiai hercegség, az 1153-1159 közötti rövid időszakot leszámítva, egész Manuel császár haláláig Bizánc vazallus állama volt. Miután Konstancia második férje, Chatilloni Raynald muzulmán fogságba került, ${ }^{19}$ első házasságából származó fia, Bohemond szerezte meg az uralmat. Mánuellel többszörösen is rokoni kapcsolatot alakított ki, Bohemond testvére, Mária Mánuel felesége lett, míg ő Mánuel egyik unokahúgát vette el.

A hold és csillag között trónoló uralkodó képe Angliában Oroszlánszívű Richárd pecsétjén jelenik meg. ${ }^{20}$ Richárd 1190-ben csatlakozott a III. keresztes hadjárathoz, és feltehetően Cipruson találkozott ezzel az ábrázolásmóddal, ahol az Komnenosz Izsák zászlaján is előfordult. Hasonlóképpen vagy Richárd, vagy ciprusi hatásra jelenhetett meg Touluose-i VI. Rajmond (1156-1222) 1204-ből származó pecsétképén is, aki Oroszlánszívű Richárd sógora, és később, egyes feltételezések szerint, egy ideig Izsák veje is volt. A nap és hold szimbólum fordított sorrendben feltünik IV. Ottó császári pecsétjén 1209-ból, valamint 1210-ből Hildebrand von Tuszien őrgróf számára kiadott aranybulla ábrázolásán. Hasonló pecsétet használt a császár hitvese, Brabanti Mária is. ${ }^{21}$ (16. ábra)

19 E házasságból született Chatillon Ágnes/Anna III. Béla felesége.

20 Itt meg kell jegyezni, hogy az angol királyok érme és pecsétképében az uralkodó oldalán ábrázolt csillag már jóval korábban jelen van, elég csak Hódító Vilmos pennyjére vagy István király pecsétjére gondolnunk.

21 Takács 2012. 32-33. 


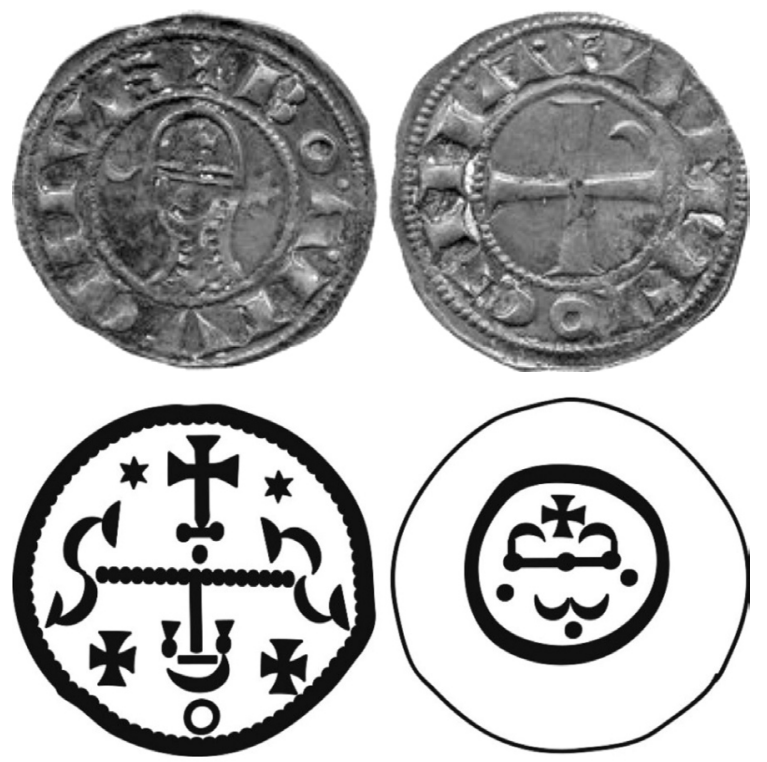

15. ábra. Antióchiai III. Bohemond (1163-1201) dénár és III. István érme (CNH 122.)

Nálunk II. András idejében jelenik meg ez az ábrázolásmód az uralkodói pecséteken (pl. második nagypecsétje 1216 előtt, aranybulla), ahol a király jobbján a nap, míg bal felöl a hold és felette a csillag helyezkedett el. Ez az ábrázolásmód a szlavón báni dénár kettős keresztje mellett még a 13. század derekén is használatban volt. Meg kell azonban említeni ennek előzményét III. Béla 1189-90 közé datált, előlapján pajzsba foglalt kettős kereszttel ellátott dénárjában, ahol a hátlapon felül két csillag-, alul egy félholdábrázolás között talán egy stilizált koronát láthatjuk, kereszttel, függőkkel.
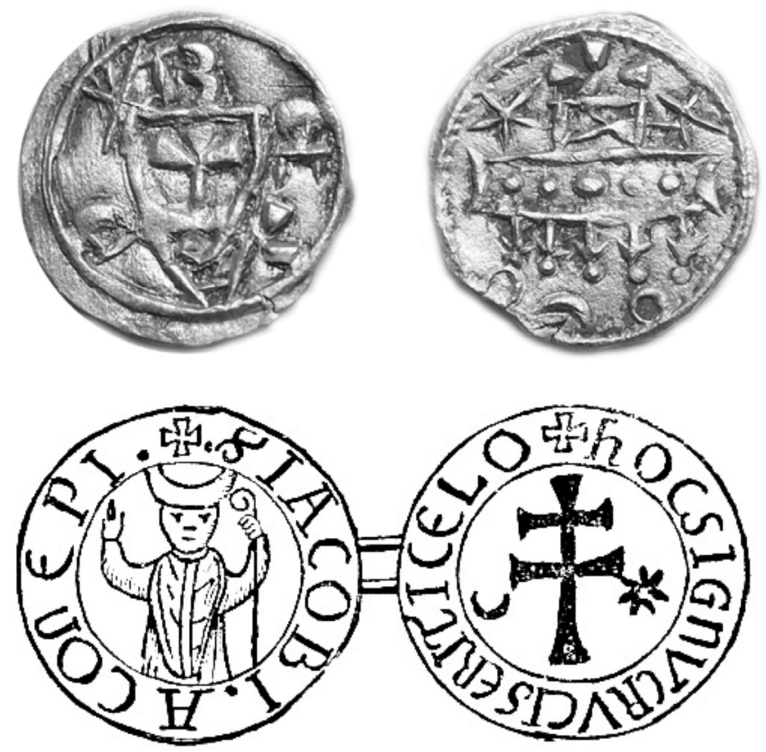

17. ábra. III. Béla dénárja 1189-1190 k. (CNH 263) és Jacques de Vitry pecsétje (1214-1225)

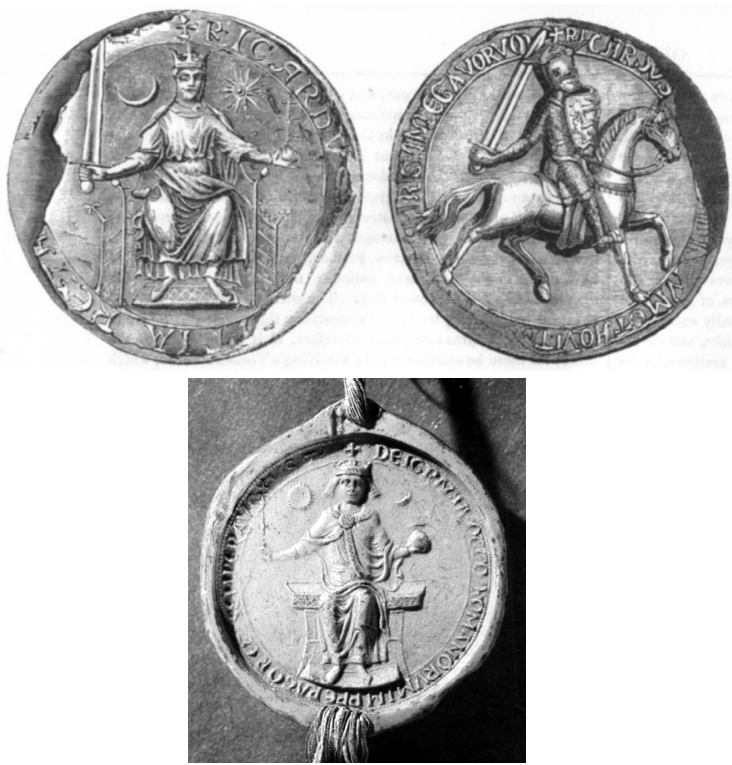

16. ábra. Oroszlánszívü Richárd (1189-99) és IV. Ottó császár pecsétje (1209) hold és csillagábrázolással

A nap és hold ábrázolás a keresztes államokhoz kapcsolódhat - amire a korábban felsorolt uralkodók keresztes hadjáratokban való aktív vagy passzív részvétele mellett alátámaszt az is, hogy Jacques de Vitry, Akkó püspöke ezt a szimbólumpárt, mind pecsétjén, mind mitráján, mind pedig hordozható oltárán megjelenítette. (17. ábra)

Ritkábban fordul elő a cipruspár közötti ábrázolásmód, bár a szicíliai normann múvészetben a 12. századra arab hatásra elterjedtté vált. Nem lehet figyelmen kívül hagyni a Monomachos korona cipruspárjait, illetve a Khakhuli triptichon Mária ábrázolását sem, ahol a ciprus törzsén cikkcakk alakban hajlított rekesz is megfigyelhető. (18. ábra) Egy sírból, a II. bolgár föváros, Tarnovgrad melletti Elenaból származik, az az enkolpion, amelynek hátoldalán cipruspár által övezett kereszt látható és hasonló ábrázolást figyelhetünk meg a velencei Szt. Márk székesegyház kincstárában őrzött dóm alakú füstölön az Okosság megszemélyesített alakjának két oldalán. ${ }^{22}$ Ugyan nem cipruspár, de egy növénypár között ábrázolt alak található a 12 . század végi Sztaraja Rjazanyi kincslelet (1822) egyik darabján, szív alakú filigránokkal, ékkövekkel díszített keretbe foglalva. (19. ábra)

Ugyanakkor a 12. század második felében már a nyugati művészetben sem idegen a két fa közötti trónoló Krisztus ábrázolása, igaz az előbbieknél stilizáltabb formában, amire jó példa a Szt. Szerváciusz relikviáit őrző Maastrichti ereklyetartó, az ún. Noodkist. Ehhez hasonló, álló Krisztust ábrázoló kisméretű ikont őriznek a Saint Denis katedrális kincstárában. ${ }^{23}$ (20. ábra) A ciprusok és egyéb növényi díszítések ábrázolásának elterjedése a nyugati mủvészetben feltehetően a szicíliai normann 22 Kiss 2001.69-70. 12. századi Dél-Itáliai munka.
23 Buckton 1984. 262. 


\section{ÚJABB ADALÉKOK AZ ÚN. „CORONA LATINA” DATÁLÁSÁNAK PROBLEMATIKÁJÁHOZ}
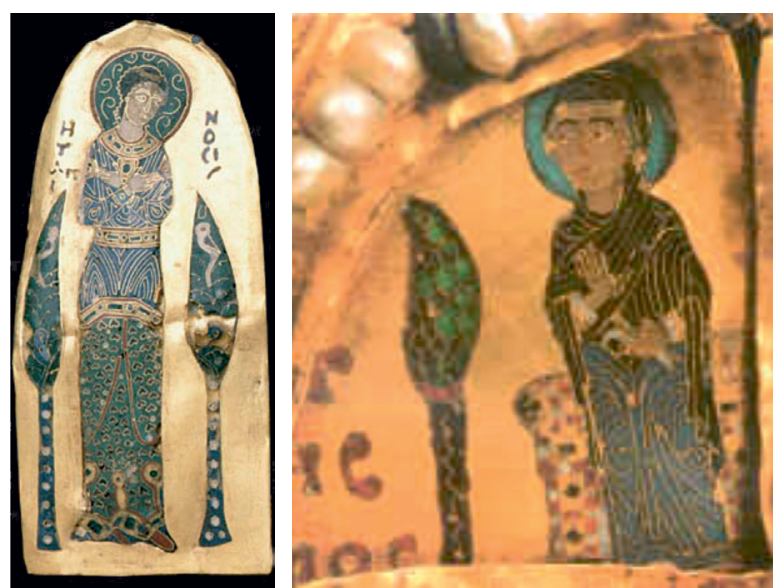

18. ábra. A Monomachos korona Alázat alakja és a Khalkuli triptichon
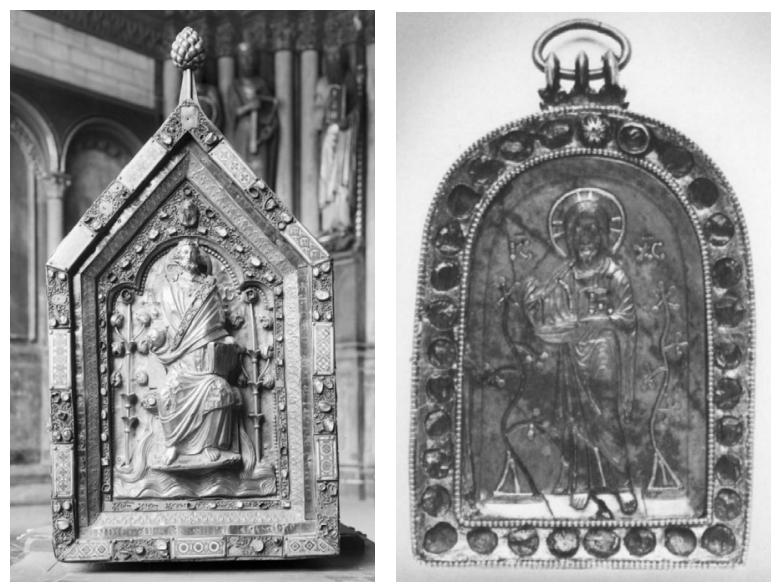

20. ábra. Szent Szerváciusz ereklyetartó (1160 k.) és 12. sz.-i kis ikon a Saint-Denis katedrális kincstárából
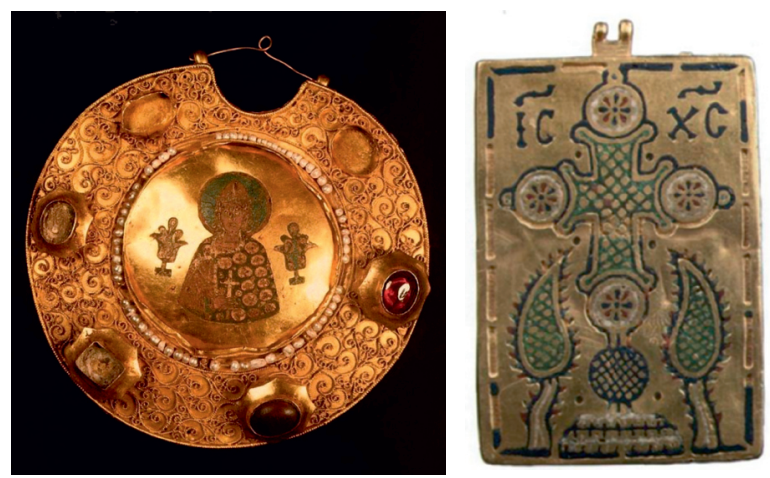

19. ábra. Növénypárral övezett szent alakja Rjazanyból és bizánci ereklyetartó hátoldala cipruspárral egy 12. századi sírból királyság közvetítésének köszönhető, hiszen a Palermói Cappella Palatina mozaikjain már a 12. század közepén megjelennek, aminek hatása mind a velencei (Szt. Márk székesegyház kupola), mind pedig a római ( $\mathrm{S}$. Paolo fuori le Mura apszis) művészet felé kisugárzott.

\section{Kereszt:}

Milyen lehetett a koronán található eredeti kereszt? Talán hasonlított a német-római koronán található mellkeresztre, amely a feliratok alapján II. Henrik idején készült, és sógora révén kerülhetett Szent Istvánhoz. Ugyanakkor érkezhetett Bizáncból is, hiszen egy kései lengyel forrás szerint a görög császár Szt. Istvánnak keresztet adományozott, amely a szent kereszt egy darabját foglalta magába. ${ }^{24}$ (21. ábra) Az írások szerint hasonló - ugyancsak Szt. Istvánhoz köthető keresztet vitt magával II. Géza a halicsi hadjárata során. ${ }^{25}$ Amennyiben bizánci gyökerű volt ez a kereszt elképzelhető a kettős kereszt kialakítás. Mindenesetre figyelemre méltó, hogy milyen fontos volt ezt a keresztet Szt. Istvánhoz kötni II. Géza idejében. Bár vitathatatlanul lényeges elem a folytonosság hangsúlyozása az Árpád-házi királyok számára, a szentséget minden bizonnyal a keresztben ereklyeként elhelyezett Jézus keresztfájának darabkája biztosította. Ily módon érthető, hogy a Pantokrátor lemezbe való beillesztése miért tủnt elfogadhatónak a korona összeállítását végzők számára. A koronán ma található kereszt a 16. századra datálható. ${ }^{26} \mathrm{Az}$ eredeti kereszt, melyet Izabella királyné 1551-ben választott le az I. Ferdinándnak átadott koronáról fia számára, és melyet János Zsigmond haláláig a nyakában hordott, Báthory Zsigmondon keresztül végül 1610-ben II. Rudolf császárhoz került. ${ }^{27} \mathrm{~A}$ fenti aktus a pars pro toto elv érvényesülése mellett a kereszt szellemi értelembe vett értékére, szakralitására is rávilágít.

\section{Keret díszítése:}

A keret egyértelműen a keresztpánt kialakítása érdekében, a zománclemezek rögzítése, egymáshoz illesztése céljából készült, így lehetett a többitől eltérő méretű a középső Pantokrátor lemez befogadására szolgáló keret. Az apostollemezeket és a Pantokrátor lemezt sodrott huzalból készített felezett szívpalmetta alakú filigrán között fogazással díszített lemezbe foglalt kör alakú gyöngyök és csepp alakú piros almandin kövek díszítik. A keret külső és belső oldalát arany gyöngysor szegélyezi. Bár vitathatatlan a filigrán dí-

24 Bertényi 1983. 67. Jan Dlugosz (1415-1480) krónikája alapján. Imre herceg adománya alapján e kereszt a Lysa Gorai bencés apátságba került. A herceg a nyakából levéve adta át a keresztet Vitéz Boleszlávnak.

25 Kristó-Makk 2003. 201., Bertényi 1983. 68. 1151-ben erre a keresztre tett esküt Vlagyimir halicsi fejedelem, majd esküszegését követően, a forrás szerint a keresztbe elhelyezett nagy erejű ereklye miatt halt meg.

26 A nyilvánvaló történeti adatok mellett a koronát vizsgáló ötvösök is hasonló véleményre jutottak. Péri-Papp 1994. 9.

27 Dr. Veress Endre: Izabella királyné 1519-1559. 1901. 6. könyv. http://mek.oszk.hu/05800/05808/html/ A kereszt letöréséröl egykorú lengyel forrás (a Bielski krónika) számol be. 

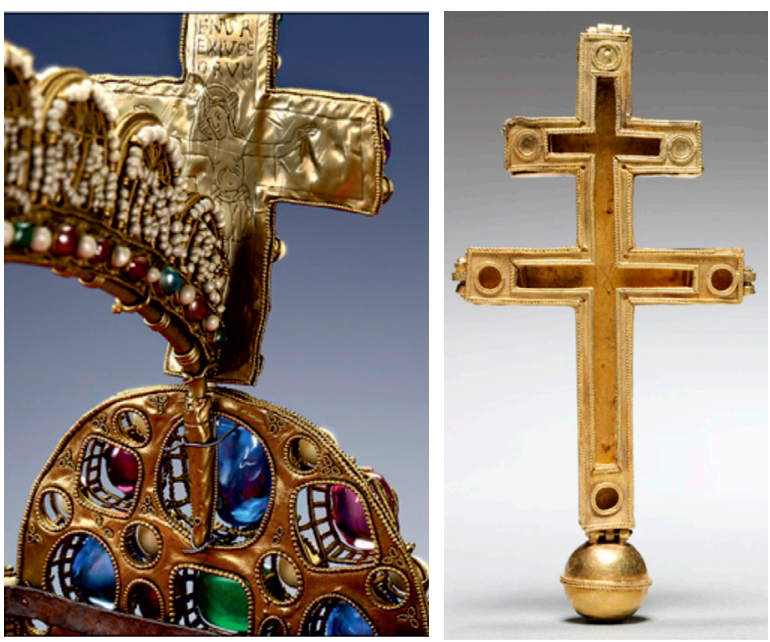

21. ábra. Kereszt a német-római császári koronáról és ereklyetartó kereszt a jeruzsálemi királyságból (12. sz.)

szítés hosszú időszakon keresztül való alkalmazása, némely apró részlet megfigyelése talán segíthet annak datálásában. A felezett szív alakú filigrán felső vége szinte teljesen kör alakban visszahajlik, míg belsejében egy vele ellentétes tájolású kisebb felezett szív alakú filigrán található alul visszahajló körrel, illetve a kettő között elhelyezkedő oldalággal. A nagyobbik filigránból felfelé egy vele ellentétes ívü, visszahajló ágacska nyúlik ki. Ez a motívum mind függőlegesen, mind vízszintesen tükrözött, ezek közé helyezték el felváltva a drágakő berakásokat. ${ }^{28}$ Egy másik különlegessége, hogy a drótok nem folyamatosak, minden hajlított darabot egyenként forrasztották fel az alaplemezre. A filigrán kiképzésére talán legközelebbi párhuzam a székesfehérvári királysírokban talált lemezkéken, a gyermek III. László sírjából (+1205) előkerült aranyleleteken és a jogar fején fordul elő. ${ }^{29} A$ drágakövek elrendezése egyértelműen utal az Árpádház címerére, amelynek címerként való használata először Imre uralkodása alatt (1202-től) jelenik meg. Úgy tűnik, hogy a filigrános keret megalkotóját mindenképp a III. Béla idejében már működő ötvösmühely egyik aranyműveséhez kell kötnünk. Kovács Éva szerint a párhuzamként adódó Szt. Oswald fejereklyetartó koronájának trapéz alakú lemezei a 12. század második felében a magyar királyi udvar ajándékaként került a Welfek birtokába, amit a fehér gyöngy és piros gránát keret is alátámasztani látszik. ${ }^{30} \mathrm{~A}$ Welf kincsek részét képező, a 12. század

28 A filigrán párhuzamként tekinthetők a Hildesheimi liturgikus legyezők és a már említett rjazanyi kolty.

29 A legújabb kutatás szicíliai párhuzamok alapján felveti a jogar 12. századi, III. Béla kori keltezését. Id. Nagy Péter: Islamic art and artifacts in twelfth and thirteenth century Hungary. 2015. CEU-MA szakdolgozata. A koronázási palást új funkciójára is a 12. század végétől van adatunk.

30 A korona másodlagosan került a 12. sz. végén készült ereklyetartóra, feltehetően több zománc és drágakő egybeszerkesztése révén. Trapéz formája másodlagos felhasználást sejtet. Kovács Éva egy 1920-ban készült fénykép alapján elveti a trapéz alakból következően valószínűsíthető armilla azonosítást, mivel a felvétel szerint egyes lemezek hátoldala is filigrándíszítéssel volt ellátva. Pannonia Regia 211. első felére datált kereszt filigrános, gyöngyös és gránátos kiképzése bizonyára ugyancsak ehhez a körhöz tartozik, még ha a ráapplikált bizánci típusú feszület korábbra is datálható. (22. ábra)

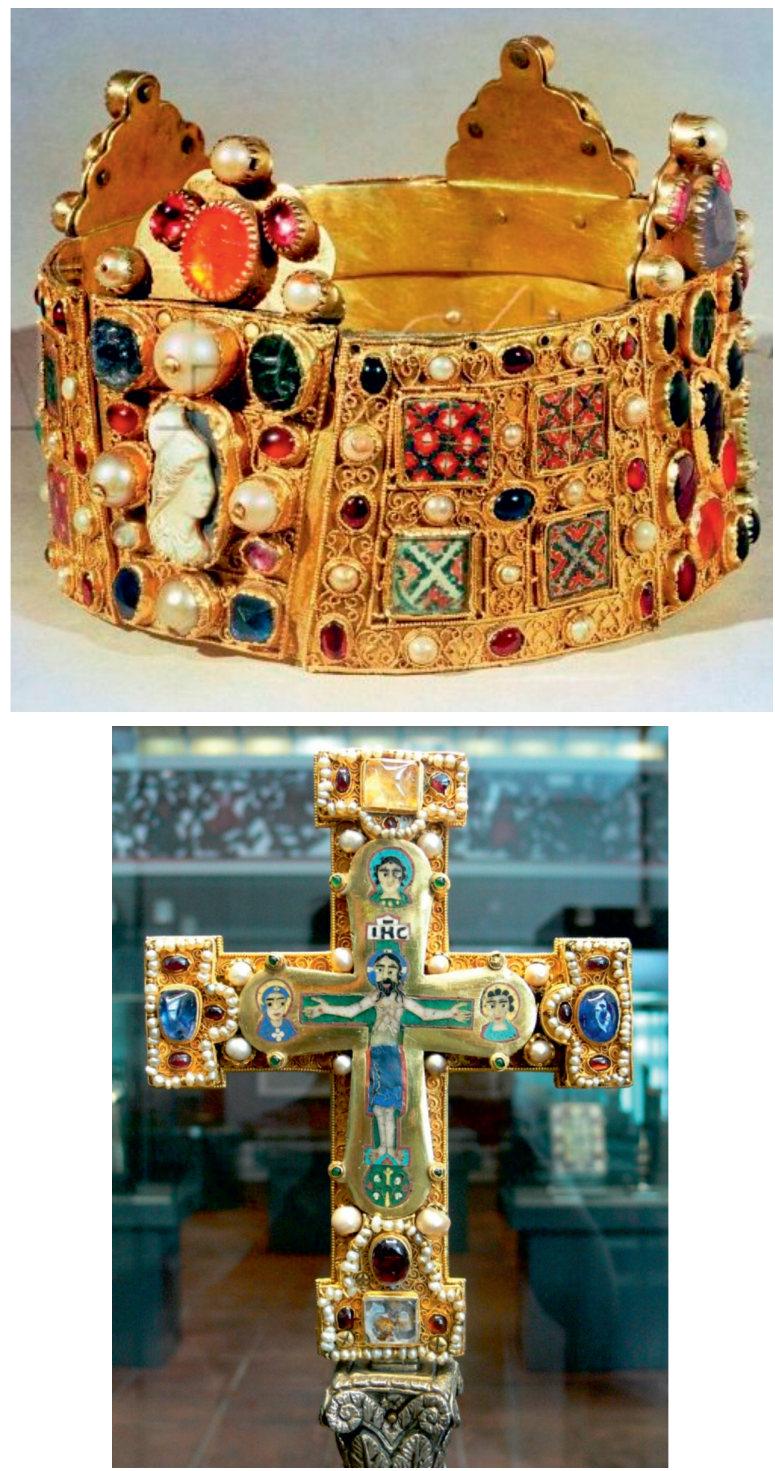

22. ábra. A Szt. Oswald korona trapéz alakú lemezei és a Welfi kereszt elölapja

\section{Bizánci és bizáncias zománcok a 12-13. század fordulójáról}

Úgy tűnik, hogy a 12-13. század fordulójára a zománcmüvesség kezdett tömegtermékké válni, és az aranynál kevésbé nemes anyagok (pl. réz) díszítésére is használták. Egyre több királyság területén kialakultak helyi mühelyek, ahol a bizánci zománctechnika elsajátításával, vagy éppen görög mesterek bevonásával készültek újabb zománctárgyak, miközben a korábbi zománctárgyak egybegyűjtése, és újrahasznosítása 
is elterjedt volt. Úgy tünik, hogy Bizánc kirablása után a zománcveretek birtoklásának és felhasználásának reneszánszát figyelhetjük meg, hisz az elrabolt, vagy kereskedelmi úton megszerzett, feltehetően több mühelyből származó veretek feltűnnek kereszteken (pl. a magyarországi eredetű Vyssi Brodi és az Oigniesi kincs/Namuri ${ }^{31}$ kettős keresztre applikált veretek), könyv borítókon. A bizonyítottan létező Palermói, Velencei és Kijevi zománcmühelyek mellett erősen feltételezhető hasonló mühelymunka Thesszalinikiben (Dumbarton Oaks-i kereszt alakú ereklyetartó, Freisingi katedrális ikonja) és a keresztes államokban is. Míg többségében görög feliratú művekről van szó, megjelennek latin felirattal, bizánci zománctechnikával készült veretek is, és itt nem csak az egyértelműen a velencei mühely alkotásai közé sorolható tárgyakról van szó (pl. III. András házioltára, Bern). A nyelvválasztás mellett sokszor az ábrázolt szentek tiszteletének elterjedése is utalhat a tárgyak készítési helyére. Így míg az ún. Dagmar kereszten a Krisztusábrázolás felett és alatt Nagy Szt. Bazil, Szt. János Chrysostomos látható - ami alátámasztja az ereklyetartó mellkereszt formáján túl is annak ortodoxiához köthető (kijevi) gyártását, ${ }^{32}$ addig a Cosenzai ereklyetartó kereszt négy evangélista ábrázolása és a ráapplikált rombusz alakú zománcok, valamint a drapéria kialakítása, a görög nyelvhasználat ellenére valószínüsíti a tárgy szicíliai készítését. ${ }^{33}$ (23. ábra) Ugyanakkor a kvalitásos kialakítású esztergomi sztaurotéka feltehetően Konstantinápolyban készült a 12. század végén. ${ }^{34} E$ kései körhöz sorolható az az aranyozott vörösréz ereklyetartó láda, amely eredetileg a zágrábi dóm kincstárában volt elhelyezve. (13. ábra)

A latin feliratú, bizánci technikával készült tárgyak köre - ha leszámítjuk a Velencei Pala d'Oro zománcait - elég szűk, legismertebb képviselője a Capuai könyvborító, a Linköpingi és a Scalai mitra, a Brixeni kesztyű és a dubrovniki Szent Balázs kar- és fejereklyetartó. A Capuai könyvborító Alfano érsek megrendelésére készült 1176-1182 között, ugyancsak a négy evangélista alakjával. Érdekessége, hogy megjelenik rajta az 1173-ban kanonizált Becket Tamás ábrázolása is. Feltehetően ez is a szicíliai műhely alkotása, hiszen a föpap, II. Vilmos király jegyese, Johanna kíséretéhez tartozott 1177-ben. ${ }^{35}$ (24. ábra)

31 Az ún. Namuri kereszt, Jacques de Vitry kereszt ereklyetartója talán a keresztes államok valamelyikében készült, korábbi, Bizáncból származó zománclemezek felhasználásával.

32 Dagmar férjének, II. Valdemarnak az anyja a Kijevi Ruszból jött Dániába. Egyes kutatók szerint nem zárható ki a Thesszalonikiben történő készítés sem. Evans-Wixom 1997. 498-499. Apja, I. Ottokár második felesége egyébként Konstancia, III. Béla és Antióchiai Ágnes lánya volt. A Krisztus feje fölötti keresztes glória tölcsérszerüen szélesedő szárának közepén díszítés található. A glória a korona Pantokrátor dicsfényének színvilágát idézi, mint ahogy a kevéssé ívelt szemöldökök is párhuzamba állíthatók.

33 A keresztet 1222-ben II. Frigyes ajándékozta a Cosenzai katedrálisnak.

34 Kutassy prímás 17. századi végrendelete alapján az ereklyetartó 1190-ben készült.

35 II. Vilmos királyi kápolnájában, Monrealéban is ábrázolta Becketet. A könyvborító Pantokrátor ábrázolása mind színében, mind kialakításában felidézi a corona latina Krisztusát.
ADubrovniki kar-, és fejereklyetartó zománclemezei bizonyítottan egy mühely termékei, amit mind a latin feliratozás stílusa, és betűformája, mind a rekeszek geometrizáló kiképzése alátámaszt, annak ellenére, hogy keretezésük
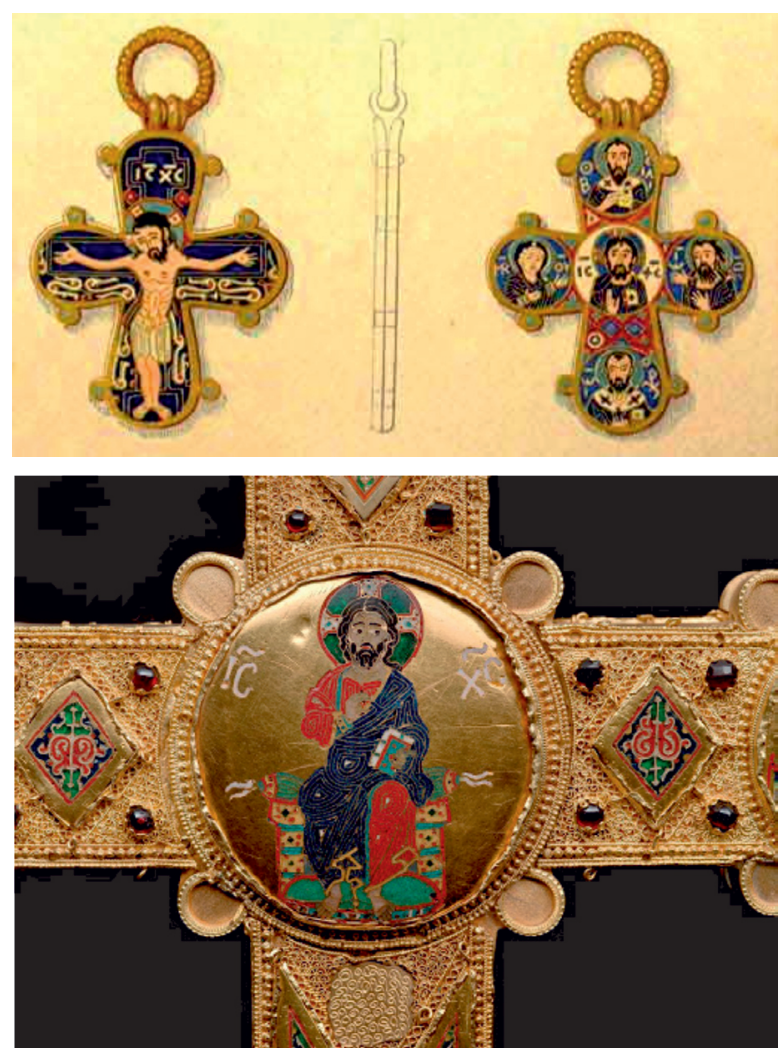

23. ábra. Az ún. Dagmar mellkereszt és a cosenzai ereklyetartó kereszt részlete

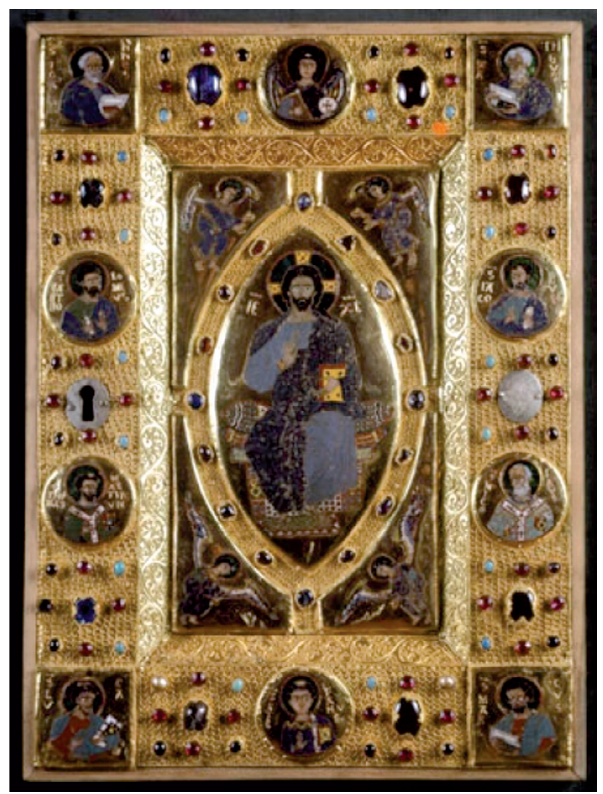

24. ábra. A capuai könyvborító Pantokrátor ábrázolása 
nagyfokú eltérést mutat. A 12. század legvégén készült zománcok felirataiban kisebb hibák figyelhetők meg, a szentek jobbján a SANCTVS felirat SAИTVS formában jelenik meg. A fordított $N$ és a kihagyott $C$ mellett a $\mathrm{T}$ betű szára jobb felé visszakunkorodik. $\mathrm{A}$ fordított $\mathrm{N}$ betű Simon nevében is előfordul. A karereklyetartón több sorban elhelyezkedő díszítéseknél a zománc lemezeket filigrándíszes szegély keretezi, míg a váltakozva előforduló, trapéz alakú növényi díszes lemezekből összerakott négyszögeket drágakövekkel díszített szegély veszi körül. A fejereklyetartó polikróm, növényi díszítésű kerete későbbi. Szent Balázs Raguzai tiszteletét a 10. századtól lehet nyomon követni. (25. ábra)
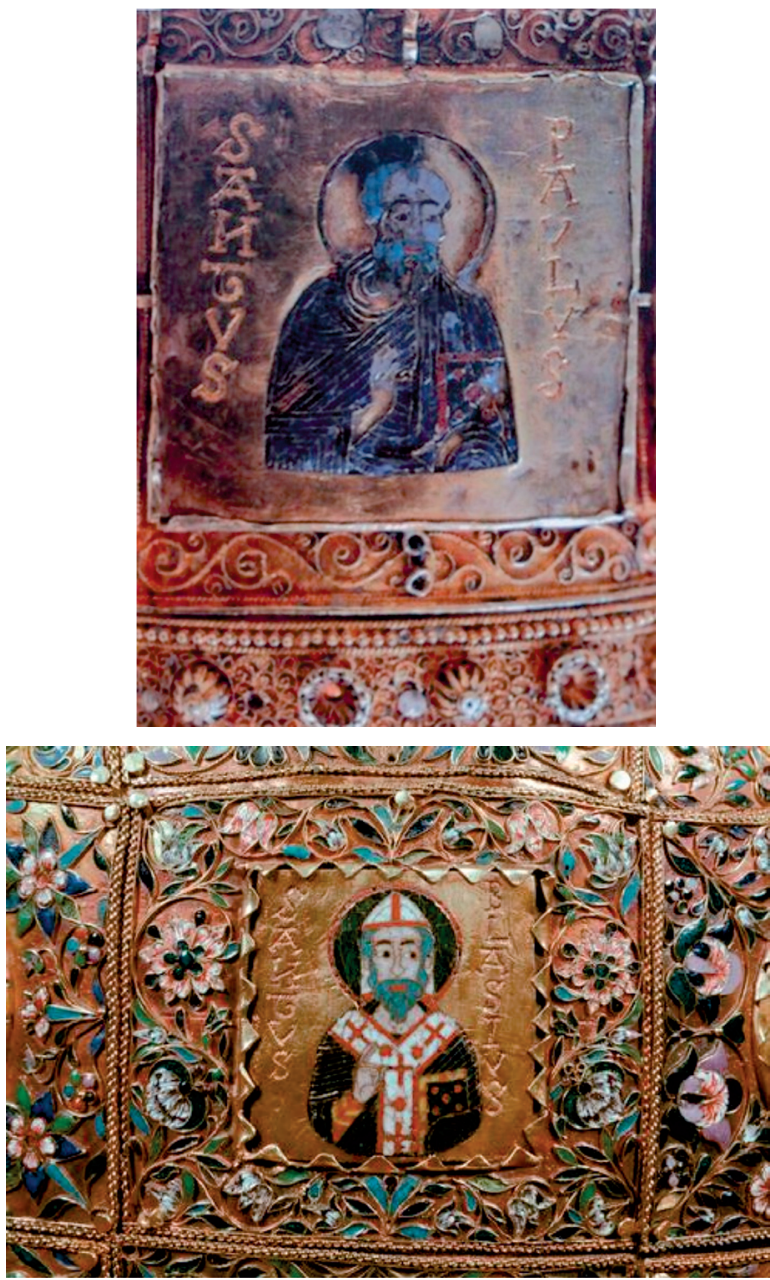

25. ábra. Szent Pál és Szent Balázs képmása a Dubrovniki kar-, és fejereklyetartóról

A dubrovniki ereklyék zománcvereteinek legközvetlenebb párhuzama az ún. svéd Linköping mitra, amelyre már Deér is felfigyelt. ${ }^{36}$ A korábbi zománclemezek fel-

36 Deér említést tesz a Dubrovniki anyaghoz tartozó, Szt. Andrást ábrázoló veretröl, melyet 1934-ben egy mükincskereskedő Horvátországban vásárolt és most a Stockholmi Nemzeti Múzeumban található. Deér 1977. 239. használásával Kettil Karlsson Linköpingi püspök a 15. század második felében készíttetett mitrát. A zománcok feltehetően Római vagy Mantovai útja során kerültek birtokába. A betűk formája, illetve a Sanctus S-ként való rövidítése azonban eltér, de a szentek ábrázolása, és a díszített trapéz lemezek alkalmazása párhuzamként jelentkezik. Mind Deér, mind pedig Buckton a zománcveretek velencei eredete mellett foglalt állást. ${ }^{37}$ Ezzel szemben a Brixeni görög feliratos, félalakos Szűz Mária ábrázolása mind redőzésében (kevésbé sűrü, koncentrikus íves, V és félhold alakú rekeszek), mind arckialakításában (befelé álló pupillák, kevéssé íves szemöldök, körte alakú orr, egyenes vonalú száj), mind pedig színeiben a korona apostol és Pantokrátor lemezeinek párhuzama. (26. ábra) Bár a Brixeni zománc származási helyét nem ismerjük, nehezen köthető a velencei mühely alkotásainak sürübb és geometrikusabb rekeszkialakításához. Úgy tűnik, hogy létezett egy különálló csoport a 12-13. század fordulóján, amelynek mühelyhez való kötése problematikus.
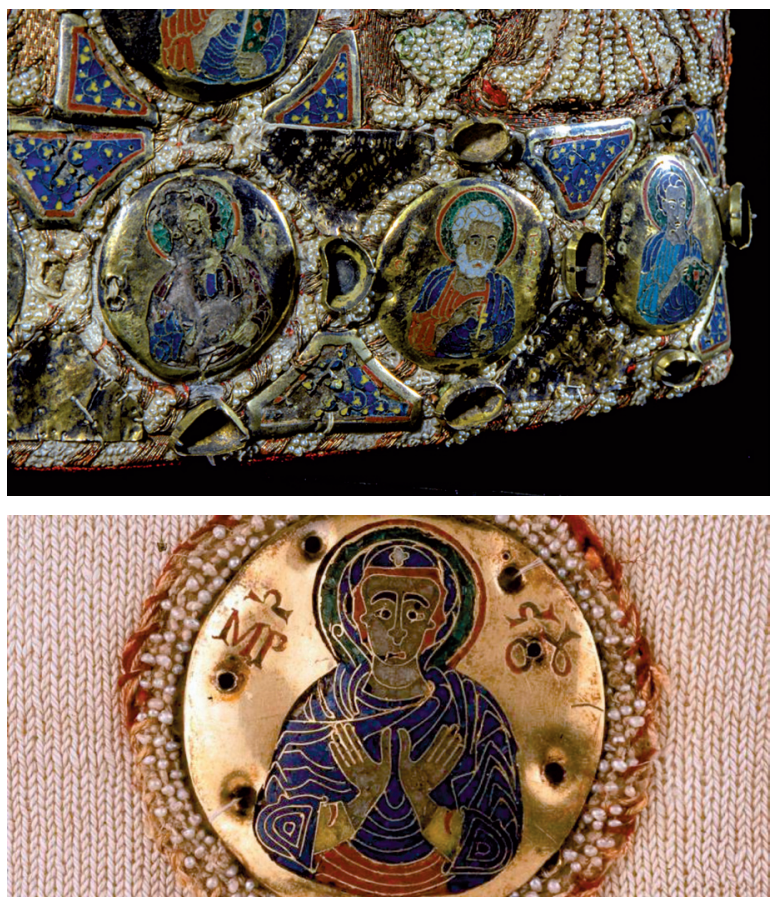

26. ábra. A Linköping mitra és a Brixeni kesztyü zománcai

\section{A bizánci művészet kisugárzása}

Már a 11. század második felétől rendelkezünk adatokkal a bizánci múvészet közvetlen kapcsolatáról, hatásáról a nyugati világgal. Desiderius Monte Cassinoi apát a Szent Benedek bazilika díszítésére bizánci mủalkotásokat rendel és művészeket szerződtet, hogy a helyi mestereket okítsák. ${ }^{38}$ A 12 . századtól mind Franciaország, mind Anglia és Olaszország irányában történik hasonló

37 Deér 1977. 250., Buckton 1984. 62

38 Tóth 2002. 217 
átvétel, ami föleg a kéziratok díszítésében mutatkozik meg. A Meuse völgyi fémművesség sem maradt érzéketlen a bizánci hatásokkal szemben, 1155-ben Wibald apát pl. 2 bizánci sztaurotékából alakítja ki egy nyugati típusú keret hozzáadásával a Staveloti monostor tiptichonját. ${ }^{39}$ A 12 század második felében a bizánci hatás kiteljesedését érzékelhetjük a szicíliai normann királyi udvarban II. Roger és II. Vilmos uralkodása közötti időszakban, amikor görög müvészeket hívtak az országba.

A bizánci kereskedelmi kapcsolatok kiemelkedő szerepet játszottak az olasz városállamok életében, hisz tudjuk, hogy 1171-ben a velencei görög kapcsolatok a Bizánci birodalomban élő velencei kereskedők kifosztása miatt romlott meg. A velencei kereskedők már I. Alexios Komnenos idejében kereskedő telepeket hoztak létre Konstantinápolyban és idővel egyre növekvő befolyással rendelkezte a tengeri kereskedelem területén. I. Mánuel a velenceiek befolyásának csökkentése érdekében más olasz városállamok kereskedőinek beengedésével próbálkozott, így jelentős befolyásra tettek szert a Genovaiak (Id. Pera), de kereskedelmi negyeddel rendelkeztek az Arany Szarv öbölben Amalfi és Pisa városának lakói is. Amikor a velenceiek megtámadták és részben elpusztították a genovaiak telepét 1171-ben, Mánuel tömeges letartóztatásokkal és elkobzással válaszolt. 1180-ban ezzel együtt mintegy 60 ezerre volt tehető a latinok létszáma a városban. Mánuel halálát követően özvegye, Antióchiai Mária régenssége alatt a latinok nyílt támogatása felszította a görög lakosság érzelmeit, így I. Andronikosz Komnenosz uralmának kezdetén, 1182-ben a latinok tömeges meggyilkolására, kirablására került sor. A velenceieknek - többek között Enrico Dandolo erőfeszítéseinek köszönhetően - 1183-ra sikerült a Konstantinápolyi velencei negyedet újjáéleszteni. ${ }^{40}$ Részben erre a mészárlásra válaszként történt Thesszaloniki 1185-ös, II. Vilmos szicíliai király által véghezvitt kirablása.

A 12-13. században a bizánci technikák és stílus nyugati elterjedése, hatása tagadhatatlan, amit Bizánc 1204-es kifosztásán túl talán a Szentföldről származó ereklyék Bizánc közvetítésével történő behozatala is szolgált. Bizánc hosszan tartó hatása a Velencei görög zománcmühely működése során jól feltérképezett, amelynek gyümölcse nem csak a Szt. Márk székesegyházban megcsodálható Pala d'Oro, hanem a Bernben őrzött, és III. András királyunkhoz köthető szárnyasoltár. A Pala d'Oro előzményét, egy kisméretű ezüst antependiumot még Orseolo Péter dózse (976-8) rendelt meg Konstantinápolyból. 1105-ben Ordelafo Faliero ezt restauráltatta, aranyból átalakítatta drágakő- és zománcberakásokkal díszítette. Egy feljegyzés szerint e munka készítői Velencében élő görög mesterek voltak. Pietro Ziani dózse (1205-29) idejében 1209-ben az oltárelőlapot megnagyobbították, a Konstantinápoly kifosztását követő rablott zománcoknak köszönhetően. ${ }^{41}$ Végső formáját a 14. sz.

39 Frazer 1970. 186-187.

40 A doge kétszer követségben járt II. Vilmos szicíliai királynál is.

41 Bettini 1984. 39-42. A zománcok eredetileg a Pantokrátor monostor díszeit képezték. közepén alakították ki. Úgy tűnik, hogy a 12. sz. elején létrejött zománcmühely végig használatban volt, hiszen a kései alkotások már latin felirattal készültek.

\section{A sokszínű bizánci-magyar kapcsolat}

A 12. század Magyarországon is a Bizánci kapcsolatok felerősödését hozta, amely egy részröl a dinasztikus házasságok révén teljesedett ki, másrészről az ütköző területek feletti hegemónia okán, katonai öszszecsapásokban mutatkozott meg. A folyamatot 1104 táján Piroska és a későbbi császár II. Komnénosz János házassága kezdi meg, majd a trónkövetelők egész sora élvezi hosszabb vagy rövidebb ideig a bizánci udvar vendégszeretetét - Álmos herceg és fia II. Béla, Kálmán elüzött feleségétől származó fia, Borisz, aki Anna Dukaina hercegnőt vette feleségül, majd fia Kálmán, 1162-1163 között II. Géza fivérei, II. László és IV. István, aki Mánuel unokahúgát, Máriát vette feleségül, majd kisebbik fia, a későbbi III. Béla, Manuel lányának jegyese, 1165/66-tól pedig a bizánci trón várományosa, majd 1172-től hitvese, Chatillon Anna révén a császári rokonságnak tagja, III. Béla öccse, Géza, Jóannész néven ugyancsak bizánci hercegnőt vett feleségül, lánya, Margit/Mária pedig 1185-ben II. (Angelosz) Izsák felesége, később pedig Monferrati Bonifáccal kötött házassága révén, annak halála után a Thesszaloniki királyság régense lett kiskorú fia Demeter mellett. ${ }^{42}$ Imre idejében a pápai orientáció erősödött meg, de II. András trónra kerülésével ismét előtérbe került a keleti politika, a keresztesek által kirabolt, immár meggyengült birodalom megszerzésére irányuló kísérlet. Gertrúd halála után 1215-ben András feleségül vette Courtenay Jolánt, konstantinápolyi latin császári hercegnőt, akinek húga Courtenay Mária nikaiai császárné, Laszkarisz Mária mostohaanyja volt. II. András 1216-17 között a konstantinápolyi latin császári korona egyik várományosának vélte magát, amely elképzelésében III. Honorius pápa levele is megerősítette. ${ }^{43}$ Többek között ez lehetett az indoka, hogy végül is rászánta magát a sokat halasztott - és még apja, III. Béla által felvállalt - keresztes hadjáratban való részvételre. Bár a katonai eseményekben kevéssé tűnt ki, az ereklyék gyűjtésében élen járt, hiszen Szt. István és Szt. Margit koponyája mellett a Kánai csoda egyik kancsóját, Áron botjának egy darabját és Tamás, valamint Bertalan apostolok jobbját is megszerezte. Az V. keresztes hadjáratról hazafelé menet 1218-ban gyermekei számára több házassági szerződést is igyekezett megkötni, így megkérte fia, a későbbi IV. Béla számára a nikaiai császár lánya, Laszkarisz Mária (1206-70) kezét, András fiát Izabella, I. Leó Kilikiai örmény király lánya számára jegyezte el, lányát, Anna Máriát pedig II. Iván Aszen bolgár királynak ígérte. ${ }^{44}$ Végül V. István lánya, Anna 1272-ben II. Andronikosz felesége lett.

42 Egyes források szerint III. Béla egyik nővére pedig Komnénosz Izsákkal kötött házasságot.

43 Bárány 2013. 463.

44 Bárány 2013. 472-474. 
A dinasztikus kapcsolatok mellett mellett kereskedelmi kapcsolatok is fennálltak a két birodalom között, 1127-ben kitört háború okai között szerepel, hogy a bizánciak a magyar kereskedőket ki akarták szorítani Barancsból, amely a Konstantinápolyba vezető út egyik fontos állomása volt.

Már Kiss Etele is felveti a Monomachos korona eredetiségét alátámasztó cikkében annak lehetőségét, hogy a korona egy, Bizánccal csak névleges vagy dinasztikus kapcsolatban álló országban készült, amint erre a későbbiekben több példa is akad. Kiss említett tanulmányában felveti egy Dalmáciában működő mủhely lehetőségét is. ${ }^{45}$ Bár a Monomachos korona zománcainak készítése idején ez elég valószínűtlennek tűnik, azonban jóval nagyobb esélyét láthatjuk ennek a 12. század közepétől. A bizánci császárok már a 11. század folyamán diplomáciai jellegü ajándékként tekintettek a zománcokra, így a fatimida kalifa mellett III. Henrik császárnak is kedveskedtek vele. ${ }^{46}$ Hasonlóan nagy mennyiségü ajándékkal együtt tért vissza Magyarországra III. Béla, azonban a corona latina apostollemezeit - már csak feliratuk okán sem - nem sorolhatjuk ezekhez. A Dalmáciai/ Délvidéki mühely - melynek létrejöttében bizonyára a bizánci ötvösök tevékeny szerepet vállaltak - feltehetően még II. Géza (vagy III. István) idején létrejött és kezdett latin írással díszített lemezeket is előállítani. ${ }^{47} \mathrm{~A}$ feliratokban rejlő bizonytalanság talán ennek az átmeneti időszaknak tudható be. Arról is van értesülésünk, hogy II. Géza 1149 folyamán követséget menesztett II. Roger szicíliai királyhoz és a francianormann szövetséghez való csatlakozásról tárgyalt. E szövetségi politika másik irányát a Welf hercegi családnak a bajor trón megszerzésében nyújtott támogatás jelentette, ami az 1140-es évek második felétől a német belpolitikába való aktív részvételével járt, és ami III. Konrád magyarországi hadjáratát is ellehetetlenítette. II. Géza viszonya a pápai kúriával az 1150-es években megromlott, „csak névleg keresztény uralkodóként” említették. ${ }^{48} \mathrm{Az}$ évtized közepét és az 1160-as évek elejét is a Bizánci birodalommal kötött békekötések jellemzik, melyek tartóssága azonban megkérdőjelezhető, hiszen korábban III. Béla eljegyzésével és Bizáncba vitelével, majd 1165ből Mánuel hódításával a szerémségi és délvidéki területek 16 évre Bizánci fennhatóság alá kerültek. Az persze kérdés, hogy mennyire jellemezte Mánuelt egy szövetségi rendszer kialakítására tett kísérlet és mennyire a közép-dalmát, horvát és szerémségi te-

45 Kiss 2001. 76

46 Kiss 2001. 76, 65. Al-Mustansirnek ötven öszvérre volt szüksége, hogy elszállítsa ezt a töménytelen kincset. Ugyancsak nagy mennyiségű zománclemez került Grúziába Dukas Muhály uralkodásának idején, amelyről a Khakhuli Triptichon tanúskodik.

47 Tóth Endre is a görög müveltség körébe tartozónak tartja a corona latina készítöit. Erre utal szerinte az a tény is, hogy az apostollemezek felirataiban előforduló $T$ és U betűk párhuzamait a görög éremverés betütípusai között lehet felismerni. Tóth 2002. 216, Tóth 1996. 198.

48 Kristó-Makk 2003. 199. Ugyanakkor, mint a ciszterci rend hazai meghonosítója, valamint a stefanita ispotályosrend létrehozója, nem kételkedhetünk II. Géza Róma iránti elkötelezettségéröl. rületekre való befolyás kiterjesztése. A Bizánci befolyás mindenesetre jelen volt a 12. század közepén a Délvidéki területeken, a konstantinápolyi pátriárka alá tartozó szávaszentdemeteri bazilita monostor müködése mellett Idriszi megemlékezett a Bács városában élő görög tudósokról, a Szerémségbe bevonuló Mánuelt pedig görög zsoltárokat énekelve fogadta a helyi papság. ${ }^{49}$ 1204-ben Imre király kísérletet tesz a bazilita monostorok szervezeti megújítására, akár külön püspökség szervezése révén, de terve nem járt sikerrel.

A bizánci művészet hatása Magyarországra a 12 . században számtalan forrásból táplálkozhatott. Nem lehet figyelmen kívül hagyni a nem direkt bizánci müvészeti impulzus hazai leképezését sem, itt elsősorban Antióchia, Szicília és Velence játszhatott szerepet. Az Antióchiából érkező hatás Antióchiai Ágnes (magyar nevén Anna), a bizánci császárné, Mária féltestvére, III. Béla felesége révén érkezhetett. Mivel felsorolással nem rendelkezünk, hogy valós tárgyakat köthessünk a házasságkötéshez, csak áttételes módon igazolható ez a kapcsolat. ${ }^{50}$

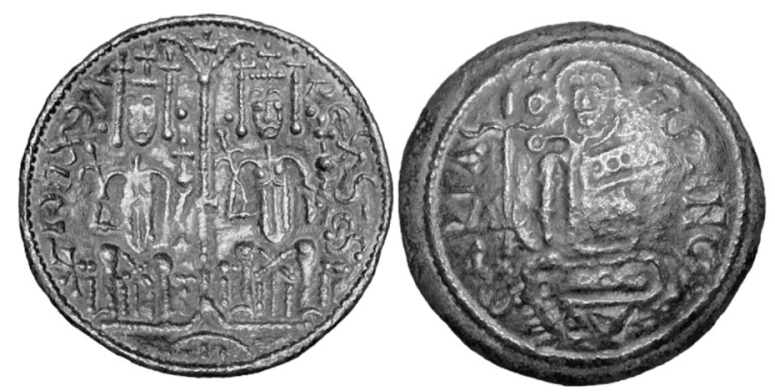

27. ábra. III. Béla réz pénzérme (CNH 98)

A bizánci hatás 12. század közepi felerősödése nem csak II. Géza 1156-os aranypecsétjén követhető nyomon, ${ }^{51}$ hanem III. Béla rézveretein is. Az egyik típus előlapján (CNH 98.) két trónoló, királyi jelvényekkel felövezett uralkodó látható Rex Bela és Rex Sts felirattal. Bár feloldásukra számos elgondolás született, legelfogadhatóbb értelmezésnek a III. Bélával és III. Istvánnal való azonosítás tűnik, amit már Jeszenszky Géza az 1930-as években is felvetett. ${ }^{52}$ (27. ábra) A veret feltehetően még III. Béla dukátusa idejére keltezhető, amikor - bizánci mintára - III. István kvázi társural-

49 Koszta László: Dél-Magyarország egyházi topográfiája a középkorban. 341-2. jegyzet internet.

50 III. Bohemond, Ágnes féltestvére dénárján találkozunk először hold és csillagábrázolással, egy sisakos, páncélos fej két oldalán. Chatillon Anna, anyja révén a normann uralkodócsaláddal, így a Szicíliai uralkodókkal is rokonságban állt.

51 A német-római császárok Nagy Károlyt követően, bizánci mintára kiváltságleveleiket gyakran aranybullákkal erősítették meg. Később ez a gyakorlat a szicíliai és aragóniai királyoknál is elterjedt.

52 Gyöngyössy 2006. 233. Jeszenszky Géza: Az első magyar rézpénzek. In: Numizmatikai Közlöny 34-35. 1935-6 35-47. A korábban felvetett Rex Scs (Sanctus) feloldás a király feje feletti dicsfény hiányában értelmezhetetlen. 
kodójaként működött az ország déli területein. ${ }^{53}$ 1161ben szervezték meg Béla hercegségét a horvát-dalmát területeken, amelyek átadására (a Szerémséggel együtt) 1163-ban, Béla Konstantinápolyba költözésekor, Mánuel is igényt tartott. Mivel békés módon ez nem sikerült 1165-ben Mánuel elfoglalta a területet és Boszniával együtt a Birodalomhoz csatolta. ${ }^{54}$ III István 1167-ben békét kötött Bizánccal, legkésőbb ettől az időponttól fogva már biztosan létezhetett ez az éremkép, amely 1172-ben, III. István halálával elveszthette létjogosultságát. ${ }^{55}$

Ugyancsak III. Béla korai pénzkibocsájtásához kapcsolható az arab/kufikus írást utánzó rézveret (CNH 103). Érdemes itt figyelembe venni a spanyol morabitino (melyek az Almoravid dinasztia érméi alapján készültek) mellett mind a jeruzsálemi és antióchiai (arany bezant), mind pedig a szicíliai normann királyság hasonló pénzhasználatát (arany tari, réz follari), annál is inkább, mivel ezek korban közelebb állnak a magyar éremhasználat időpontjához. (28. ábra) A szicíliai normann királyság mind földrajzi, mind pedig kulturális értelemben az arab és a keresztény világ találkozásában helyezkedett el, és így alakulhatott ki egy olyan művészet, amely a bizánci, mór és nyugat európai hatásokat ötvözte. Az 1070-es éveket követően, egészen Frigyes haláláig a királyságot etnikai és vallási tolerancia jellemezte. Bár a latin nyelv volt hivatalos, a fontos dokumentumoknál az arab, a görög és a héber nyelvet is használták, amiröl egy 1148-as sírkő többnyelvű felirata is tanúskodik. ${ }^{56}$ Mind a törvényhozásban, a pénzverésben, mind pedig az intézmények létrehozása terén történtek átvételek a szomszédos arab emírségektől. Úgy tűnik, hogy a 12. század harmadik negyedében a szicíliai királyság, a keresztes államok és a bizánci birodalom környezetében kialakult egy erős kulturális kölcsönhatás, amelynek tanúbizonyságát nem csak az említett éremképek adják, hanem pl. az Artukida uralkodók bizánci vereteket utánzó érmeképei (pl. Kara Arslan 1144-1174 pénzén a trónoló Krisztus ábrázolás) is. III. Béla kísérlete - a rézpénzek törvényes fizetőeszközként általánossá tétele - azonban nem sikerült, körülbelül egy évtized eltelte után a királyi kincstár visszatért az ezüstpénzek veréséhez.

53 A társuralkodásra van korábbi példa 1152-ból II. Géza és III. István kapcsán. Kristó-Makk 1996. 190.

54 Az 1167-ben indított hadjárat elött történt, hogy a Konstantinuszi fórum nyugati diadalkapuján lévő 2 ércszobor közül a bizánci nőt ábrázoló szobor ledőlt, amit Manuel a hadjáratra nézve rossz előjelként értelmezett, ezért elrendelte, hogy a másik szobrot, ti. a magyar nő szobrát döntsék le, és a görög nő szobrát állítsák vissza. Moravcsik 2003. 83

55 Kristó-Makk 2003. 225. 1170-ben az újdonsült házas Béla Konstantinápolyból Antióchiába és Jeruzsálembe utazott, mint Magyarország, Dalmácia és Horvátország hercege. 1172-ben Oroszlán Henrik is zarándoklatot tett a Szentföldre.

56 Grisanto pap anyja emlékére Palermóban négynyelvű sírfeliratot emelt.
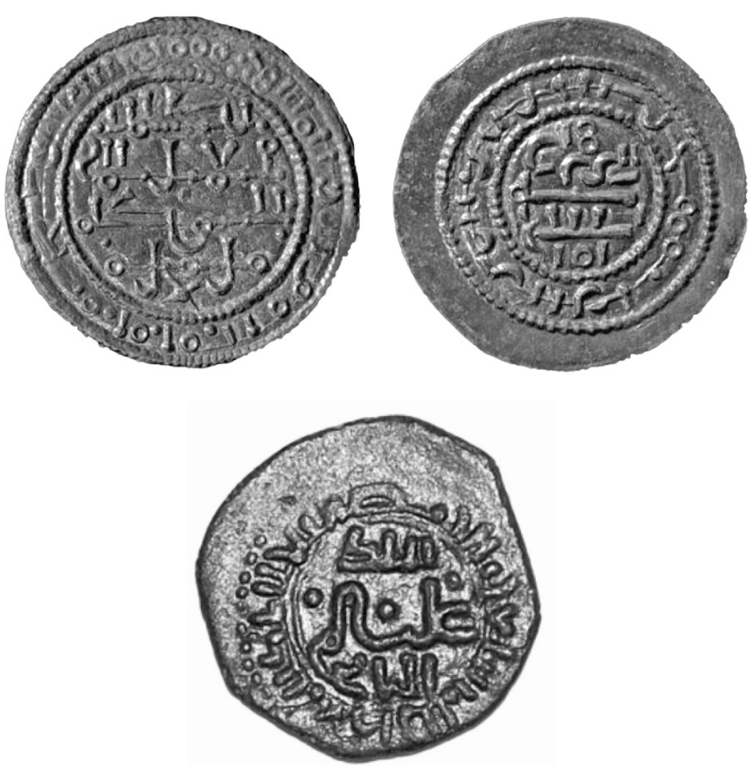

28. ábra. III. Béla rézpénze és II. Vilmos (1166-1189) follisa ${ }^{57}$

III. Béla Esztergomban, ahol a király ötvösműhelyet is müködtetett, ${ }^{58}$ nagyszabású építkezésekbe kezdett, ahol a díszítések részben bizánci gyökerekből táplálkoztak (pl. kápolna freskó). Feltehetően az ötvösműhelyben is dolgoztak bizánci gyökerű mesterek. Bizonyosak lehetünk afelöl, hogy III. Béla neveltetése mellett a Szerémség és Délvidék 16 évig tartó bizánci fennhatósága is hozzájárult a bizánci művészet magyarországi elterjedéséhez. Úgy tünik, hogy a 13. század elején a Bizáncból korábban megszerzett zománcokat - köztük III. Béla enkolpionjához (3. ábra) hasonló lunetta alakú lemezeket - másodlagosan is feldolgozták, elég itt a cseh Vyssi Brodban őrzött kettős kereszt alakú sztaurothékára gondolnunk. ${ }^{59}$

Érdekes kérdést vet fel III. Béla vallásgyakorlata. Azzal, hogy 1166 márciusában Mánuel oldalán trónörökös jelöltként egyházi zsinaton vett részt Konstantinápolyban, ekkor bizonyára az ortodoxia követőjének kellett hogy vallja magát. ${ }^{60}$ Nem lehetett véletlen 1172ben Lukács esztergomi érsek Béla koronázásával kapcsolatos ellenérzése, bár ekkorra már bizonyára visszatért a katolikus hitre. Úgy tünik azonban, hogy az ortodoxia hatása nem múlt el nyomtalanul, mivel 1183-ban rilai Szent Iván ereklyéit hozta el Szófiából, azonban a keleti szent tiszteletét nem tudta Magyarországon meghonosítani.

57 A follis középén II. Vilmos király, a köriratban "bi-amr al-malik almu'azzam al-musta'izz" olvasható.

58 Kristó-Makk 2003. 231

59 Evans-Wixom 1997. 441-442, 497. Az enkolpion ornamentikájának párhuzamait Aragóniai Konstancia halotti koronáján lehet megfigyelni.

60 Kristó-Makk 2003. 224 


\section{Az állami jelvények és a korona mai formájának ki- alakulása}

Magyarországon a királyság állami jelvényeinek megjelenése nem tehető a 12. század elé, ekkortól jelenik meg az állami címerhasználatban előbb a kettős kereszt, majd Imre uralkodásától fogva a vágott címerpajzs. Úgy tünik, hogy ekkortól datálható a Gizella királyné által adományozott miseruha koronázási palást szerepe és jelenik meg a jogar is.

A 12. században egy megkülönböztetett szerepü koronáról már maradtak fenn írott források, amit alátámaszt II. Andrásnak az osztrák herceg irányába tett háborús fenyegetőzése, amit a gyermek III. László és anyja által az országból kivitt korona visszaszerzése érdekében tett. A korona őrzésére már III. Ince pápa 1198-ban kelt oklevele is rávilágít, amikor a fehérvári őrkanonok tisztjeként említi királyok koronájának őrzését. ${ }^{61}$ Hasonlóan a királyi korona őrzési helyeként szerepel Székesfehérvár Mihály konstantinápolyi pátriárka Mánuelt dicsőítő beszédében (1165-7). „A te jogarod alatt vétessen jegyzékbe Paionia koronás temploma a körülötte levő székvárossal, hogy a paion uralkodók királyi koronája a te hatalmasságodnak legyen függvénye." ${ }^{2}$ A korona a 1256-ban már megkapja a szent jelzőt, 1292-re pedig kialakul az az elképzelés, hogy Szt. István koronája volt, ${ }^{63}$ ami nem véletlen, ha belegondolunk III. András legitimációs problémájára, aki ily módon is ki akarta hangsúlyozni az Árpád-házhoz való tartozását.

III. Béla, mint a császári méltóság várományosa és a császár lányának, Máriának jegyese fiatalkorát Mánuel udvarában töltötte, ahol a számára kreált despotesi címmel is felruházták. Bár a frigy nem jött létre és Mánuelnek saját utódja született, ${ }^{64}$ a jó kapcsolat a császár és Béla/Alexios között fennmaradt. loannes Kinnamos történetíró művében így emlékezik meg Béla magyar királlyá történő meghívásáról „Mialatt itt tartózkodott (t.i. Mánuel Sardikéban volt) a hunok követeket küldve azt kérték, hogy küldje el nekik Bélát királyul, mivel István halála után a jog rendje őt választja. Béla előbb a császár vejének volt kijelölve, mint ezt már mondtam, de mivel a rokonsági törvény ennek útjába állt, az augusta nővérét vette feleségül. Így kaisarnak kiáltatott ki, s méltóság tekintetében az akkori bizánci nagyok közt kiváló helyet foglalt el. A császár őt királylyá nyilvánítva, feleségével együtt a hun földre küldte, miután Béla esküvel kijelentette, hogy minden időben azt teszi a mi a császárnak és a rómaiaknak elönyös. A császár megbízásából, hogy méltóságába beiktassák, elkísérte őt loannes protosebastios és más hí-

61 Tóth-Szelényi 1999. 13-14. Ekkor a korona már kiemelt szerepet látott el, mivel a „diadema regiumtól” függött a nemzet méltósága. Deér 2005. 174

62 Moravcsik 1988. 155. Érdemes megjegyezni, hogy ez a passzus a királyság alárendeléséről, és nem konkrét koronáról szól.

63 Zsoldos 2000 (História) 1240-ben egy francia szerzetes arról számol be, hogy a magyar királyokat Szt. István trónjára ültetik és felszerelésével díszítik királlyá szenteléskor.

64 A Bélának tett eskü átruházása 1171-ben történt a Blachernai templomban és 1172-ben a császár már uralkodótársának nyilvánította a fiat. Moravcsik 1988. 292. rességek." ${ }^{65}$ Egy 13. század elejéből származó forrás szerint „Mánuel...elküldi Alexiost fényes kísérettel és teljes uralkodói felszereléssel, hogy átvegye a paion uralmat, és uralkodjék honfitársai felett."66 Bár a forrás kétségkívül a császári udvar érdekeinek szellemében íródott, az azonban bizonyosnak tünik, hogy Bélát bizánci kísérettel látták el. Arra, hogy Bélát egykori bizánci ambíciói uralkodása végéig nem hagyták nyugodni, jó példa özvegysége idején, 1185-ben tett kísérlete, amikor Theodora Komnenével, Mánuel császár rokonával tervezett házasságát próbálja előmozdítani. 1185-re már meghalt Mánuel és fia II. Alexios Komnenost pedig megölette Andronikos, így a koronázásakor tett ígéret elévült. A frigyből végül nem lett semmi, mivel a zsarnok Andronikos Komnenos Theodorát korábban, férje halála után, kolostorba kényszerítette (megnyíratott). Tanúságos, hogy 12. század második felében, Theodoros Balsamon által írt kommentár alapján, más előkelő nőknél az apácasorsba kényszerítést annulálni lehetett. ${ }^{67}$ Feltehetően a magyar származású császártól való félelem lehetett a fő ok, amiért Theodora a feloldást nem kaphatta meg.

A zárt császári korona kialakulásának pontos dátumát Anna Comnena, apja (Alexios I., +1118) emlékére írott múvéből ismerjük. „A császári diadem vagy tiara egy félgömb alakú, fejre simuló sapkára hasonlított, amelyet igazgyöngyökkel és drágakövekkel sürün beborítottak, némelyiket rögzítették, némelyik pedig lelógott és a homlok mellett két oldalt igazgyöngyből és drágakőből két hajtóka csüngött egészen az orcákig." ${ }^{68}$ A zárt korona - az ábrázolások alapján - ettől kezdve végig használatban maradt, nem csoda tehát, hogy azokban a királyságokban, ahol erős bizánci hatással számolhatunk, vagy a császári trón megszerzésének törekvése felsejlik, szintén elterjedt. Ilyen például Szicília, ahol Aragóniai Konstancia kamelaukionján kívül, a Palermói székesegyházban Szicíliai Konstancia (1154-1198) és fia, II. Frigyes császár (1194-1250) porfír szarkofágján található ábrázolás is tanúskodik. (29. ábra) A két szarkofágot, melyek eredetileg a Cefalúi bazilikában álltak, 1145-ben, mint II. Roger szicíliai király adományát említik, melybe végakarata szerint temetkezni kívánt. Az üresen maradt szarkofágokat II. Frigyes 1215 körül Palermóba viteti, és szüleit helyezi el bennük. Úgy tủnik, hogy a szarkofágokat ekkor felcserélik, mivel VI. Henrik szarkofágja női koronával (+1197) Konstancia szarkofágja pedig zárt koronával van díszítve. ${ }^{69} \mathrm{~A}$ zárt korona Szicíliai elterjedésére utal az is, hogy II. Vilmost, a Monrealei katedrális kerengőjében, mint adományozót így ábrázolták.

65 Moravcsik 1988. 246. III. István 1172. március 4.-én halt meg, Bélát 1173. január 13.-án koronázták magyar királlyá.

66 Niketas Choniates történeti munkája, Moravcsik 1988. 293.

67 Moravcsik 1988. 256

68 Anna Comnena: The Alexiad translated: Elisabeth A.S. Dawes, Cambridge Ontario 2000. 56. http://www.yorku.ca/inpar/alexiad_ dawes.pdf

69 Varga 1994. 9. Deér szerint a Cefalúi szarkofágok II. Frigyes és VI. Henrik szarkofágjai voltak. 

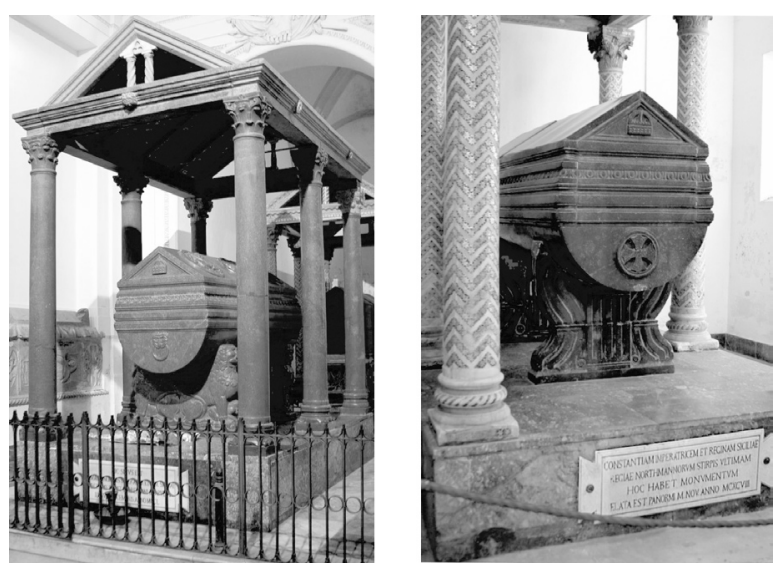

29. ábra. Kamelaukon ábrázolás II. Frigyes és anyja szarkofágjáról, Palermo

\section{Összegzés}

A corona latina keletkezési idejét tehát valamikor a 12. század közepére, második felére helyezhetjük; II. Géza és III. Béla uralkodásának ideje közé. Alkotója bizánci gyökerekkel vagy legalább a zománctechni- ka és motívumkincs ismeretével rendelkezett. Ebben az időszakban aktív külpolitikát folytatott a magyar királyság, úgy tünik, hogy nagyhatalmi ambíciókat is dédelgetve. Mánuel alatt Bizánc külpolitikájában felerősödik egy nyugati irányú terjeszkedés gondolata, amely konkrét ütközésekhez vezet a Szerémség területén. $E$ korszakot többszöri békekötések, dinasztikus házasságok és ezek révén a magyar belpolitikába történő nyílt beleszólás is jellemezte Bizáncot. A zárt korona létrejötte feltehetően az 1180-85 közötti időkre datálható, Mánuel halála után, amikor III. Béla nyíltan aspirált a bizánci császári címre. Első lépésként viszszafoglalta Horvátországot, Dalmáciát, a Szerémséget és Boszniát és terjeszkedett Szófia irányában is. Ekkor kellett zárt koronát készítenie, mivel a császárrá koronázás ismérvei között szerepelt a kamelaukion használata is. ${ }^{70} \mathrm{~A}$ korábban, talán már II. Géza alatt elkészült - eredetileg ereklyetartót vagy könyvborítót díszítő zománclemezeket - mivel azok kevéssé voltak hajlíthatók - keretbe foglalva egy filigrános pántra applikálta, amelyet a nagyobb erőhatásoknak kitéve törések, repedések értek, erre a későbbi megerősítések nyomai is utalnak.

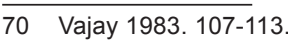

\section{Irodalom}

BÁRÁNY A. 2013: Bárány Attila: II. András és a Latin Császárság. Hadtörténelmi Közlemények 126. Budapest 2013. 2. 461-480.

BERTÉNYI I. 1983: Bertényi Iván: Kis magyar címertan. Budapest 1983

BETTINI, S 1984: Sergio Bettini: Venice, the Pala d'Oro and Constantinople. IN: David Buckton ed.: The treasury of San Marco Venice. New York 1984. 35-64.

BuckToN, D. 1983: David Buckton: Vorläufige Ergebnisse einer optischen Untersuchung des Emails der Krone. IN: Lovag Zsuzsa szerk.: Insignia Regni Hungariae I. Budapest 1983. 129-143.

BuckTon, D. 1984: David Buckton ed.: The treasury of San Marco Venice. New York 1984.

DeÉR, J. 1966 (2005): Deér Josef: Die Heilige Krone Ungarns. (A magyarok szent koronája). Graz-Wien-Köln 1966, (Budapest 2005.)

DEÉR, J. 1977: Josef Deér: Die byzantinizierenden Zellenschmelze der Linköping Mitra und ihr Denkmalkreis, IN.: Peter Classen ed.: Vorträge und Forschungen: Byzanz und das abendländische Herrschertum. Ausgeqwählte Aufsätze von Josef Deér. 21. kötet. Heidelberg 1977. 235-256.

Evans, H.C. 2001: H.C. Evans: The Arts of Byzantium. The Metropolitan Museum of Art Bulletin. 2001 Spring

Evans, H.C. \& Wixom, W.D. 1997: H.C. Evans - W.D. Wixom ed.: The glory of Byzantium. (Art and Culture of the Middle Byzantine Era A.D. 843-1261). New York 1997.

FrAZER, M. 1970: Margaret Frazer: Byzantine art and the West, IN: Florens Deuchler ed.: The year 1200. A background survey II. 1970 New York. 185-230.

GYÖNGYÖssY M. 2006: Gyöngyössy Márton: Magyar Pénztörténet 1000-1526. In: Gyöngyössy Márton szerk.: Magyar középkori gazdaság és pénztörténet. Budapest 2006. 227-288.

IPOLYI A. 1886: Ipolyi Arnold: A magyar szent korona és a koronázási jelvények története és müleirása. Budapest 1886.
KISs E. 2001: Kiss Etele: The state of research ont eh Monomachos crown and some further thoughts. IN: Olenka Z. Pevny ed.: Perceptions on Byzantium. New York. 2001. 60-84.

KRISTó Gy. és MAKk F. 1996: Kristó Gyula - Makk Ferenc: Az Árpádház uralkodói. Budapest 1996.

KRISTó Gy. és MAKk F. 2003: Kristó Gyula-Makk Ferenc: Az Árpádok. Fejedelmek és Királyok. Budapest 2003

MoRAVCsIK GY. 1988: Moravcsik Gyula: Az Árpád-kori magyar történet bizánci forrásai. Budapest 1988

MoRAvcsik GY. 2003: Moravcsik Gyula: Bizánc és a magyarság. Budapest 2003

Pannonia Regia 1994: Mikó Árpád-Takács Imre szerk.: Pannonia Regia. Múvészet a Dunántúlon 1000-1541. Budapest 1994.

PÉRI J. és PAPP L. 1994: Péri József - Papp László: Idöszaki jelentés a Szent Korona ötvösvizsgálatáról I-II. Magyar Iparmüvészet 1994. 2-9.

TAKÁcs I. 2012: Takács Imre: Az Árpád-házi királyok pecsétjei. Budapest 2012

TóтH E. 1996: Tóth Endre: A Szent korona apostollemezeinek keltezéséhez. Com Arch. Hung. 1996. 181-209.

TótH E. és SzELÉNYI K. 1999: Tóth Endre - Szelényi Károly: A magyar szent korona (Királyok és koronázások). Budapest 1999.

ТóтH E. 2002: Tóth Endre: A magyar szent koronáról és a koronázási jelvényegyüttesröl. IN: Veszprémy László szerk.: Szent István és az államalapitás. (Nemzet és Emlékezet) Budapest 2002. 209-226.

VAJAY, Sz. 1983: Szabolcs de Vajay: Der Kamelaukion-Character der heiligen Krone Ungars - Die typologische Rechtfertigung einer Benennung. IN: Lovag Zsuzsa szerk.: Insignia Regni Hungariae I. Budapest 1983. 101-128.

VARGA L. 1994: Varga Lívia: II. Roger szicíliai király porfír szarkofágjának jelentéséről. Ars Hungarica 1994. 7-14. 


\title{
New information to the problematic dating of the so called "corona latina"
}

\author{
CSILLA ARADI
}

While the dating of the lower part of the Hungarian Holy crown, the so-called corona graeca is relatively clear, the creation date of the cross section and the enamel plates with Latin inscriptions placed on it is more problematic, moving between a wide interval. Current paper means to provide data to support the presumption of a 12 . C. manufacturing through representation as well as stylistic and technical observations. The enamel plates according to manufacture provide a transition between cloisonné and champlevé techniques, and differ from the dense and fine wiring of Byzantine counterparts. The use of zigzag wires are characteristic which have only a few parallels from the period. A similar technique can be traced on an enameled book cover from Maastricht and a reliquary cross from Thessaloniki. David Buckton and Endre Tóth have already laid emphasis on the framed inscriptions which according to their formation, the use of a variety of characters and the appearance of majuscule together with cursive writing have parallels in the Pala d'Oro and the book cover of Sion/Sitten, and point towards the 12. C. The rhomboid form of the key head held in the right hand of S. Peter apostle similarly cannot be imagined prior to the 12. C.

Though produced without the whole plate being enameled and with the sole use of the cloisonné technique, but according to the wiring, the portrayal and the coloring, the Pantocrator plate most probably belonged originally also to the same object. The sun, moon and star symbols appear on royal seals and coins from the mid 12. C. starting from the dinar of III. Bohemond of Antioch, who was related to both Manuel and III. Béla. The cypresses depicted on two sides of Christ have numerous analogies, among others in Sicilian Norman art of the period.

The shaping of the filigree decoration on the framing bands of the enamel plates show relationship with the gold finds from the royal burials at Székesfehérvár and with the trapezoid plates of the crown on S. Oswald's head reliquary, which according to Éva Kovács was produced in the goldsmith workshop working under the rule of III. Béla and was acquired by the Guelph dynasty as a present from the Hungarian royal court.

Today we cannot give a precise answer to what the cross on the crown originally looked like as it was disconnected from the crown in 1551 by Queen Isabella for her son. We can assume that it belonged to the type of reliquary crosses which János Zsigmond wore in his neck until his death. It is likely that the holiness of the crown originated from this reliquary which explains why Isabella though it important to own it.

During the second half of the 12. C. the Byzantine art effected the Western culture at its most, its traces can be found not only in the Norman Kingdom of Sicily, in Venice and in the Crusader states but in Hungary as well. The royal usage of the gold bull can be tracked down from the age of II. Géza and on the copper coins of III. Béla a more direct Byzantine influence can be experienced. The acquisition of Byzantine enamels reached its peak with the sack of the Byzantine Empire in 1204. We have data about the opening of Greek originated goldsmith workshops from Venice and Sicily. It can be presumed that starting from 1165 with the Byzantine conquest of Southern Hungarian territories through the 16 years of occupation Greek masters appeared in this area and could have stayed after the reoccupation. As it is obvious in Venice the art of Greek masters slowly transformed and was enriched by Western influences and Latin letters appeared on their artifacts.

The creation of the enamel plates of the corona latina thus can most probably be placed to the second half of the 12. C. The long rule of II. Géza was characterized by restlessness towards the Byzantine Empire which was only partially due to the Western expansion ideal of Manuel and his direct interference in Hungarian inner policy even through dynastic marriages. Géza also cherished great aims. Despite of wars the country flourished and large-scale constructions took place. The origin of the enclosed crown can be placed between 1180 and 1185 when his son III. Béla openly aspired for the title of the Byzantine emperor. 